\title{
Net ecosystem metabolism in a micro-tidal estuary (Randers Fjord, Denmark): evaluation of methods
}

\author{
Frédéric Gazeau ${ }^{1,2,6, *}$, Alberto Vieira Borges ${ }^{2}$, Cristina Barrón ${ }^{3}$, Carlos M. Duarte ${ }^{3}$, \\ Niels Iversen ${ }^{4}$, Jack J. Middelburg ${ }^{5}$, Bruno Delille ${ }^{2}$, Marie-Dominique Pizay ${ }^{1}$, \\ Michel Frankignoulle $^{2, \mathrm{~T}}$, Jean-Pierre Gattuso ${ }^{1}$ \\ ${ }^{1}$ Laboratoire d'Océanographie de Villefranche, CNRS-Université de Paris 6, BP 28, \\ 06234 Villefranche-sur-Mer, Cedex, France \\ ${ }^{2}$ Unité d'Océanographie Chimique (B5), Interfaculty Centre for Marine Research, Université de Liège, 4000 Sart Tilman, Belgium \\ ${ }^{3}$ Institut Mediterrani d'Estudis Avançats (CSIC-UIB), C/Miquel Marquès 21, 07190 Esporles, Spain \\ ${ }^{4}$ Aalborg Universitet (AU), Sohngnardsholmsvej 57, Aalborg, Denmark \\ ${ }^{5}$ Netherlands Institute of Ecology (NIOO-KNAW), Centre for Estuarine and Marine Ecology, Postbus 140, \\ 4400 AC Yerseke, The Netherlands \\ ${ }^{6}$ Present address: Netherlands Institute of Ecology (NIOO-KNAW), Centre for Estuarine and Marine Ecology, \\ Postbus 140, 4400 AC Yerseke, The Netherlands
}

\begin{abstract}
The metabolic status, the difference between organic matter production and consumption of an estuary (Randers Fjord, Denmark) has been assessed based on 2 field cruises in April and August 2001 and a number of approaches: (1) the oxygen $\left(\mathrm{O}_{2}\right)$ incubation method, (2) dissolved inorganic carbon (DIC) budgets, (3) the response surface difference (RSD) method based on diel $\mathrm{O}_{2}$ changes and (4) land-ocean interaction in the coastal zone (LOICZ) budgets based on dissolved inorganic phosphorus (DIP). Although each method has its own associated limitations and uncertainties, the above approaches converged most of the time in consistent metabolic estimates, both in sign and magnitude, and revealed that this system was near metabolic balance in spring (net ecosystem production: NEP $\sim 0$ ) and net heterotrophic in summer (NEP $\sim-50 \mathrm{mmol} \mathrm{C} \mathrm{m}^{-2} \mathrm{~d}^{-1}$ ). In this shallow estuary (mean depth $=1.6 \mathrm{~m}$ ), the benthic compartment was very active and represented 70 and $30 \%$ of the total gross primary production in April and August, respectively. NEP rates measured during this study are in the range of previously reported rates in estuaries.
\end{abstract}

KEY WORDS: Ecosystem metabolism · Estuaries $\cdot$ Primary production $\cdot$ Respiration $\cdot$ Randers Fjord • Oxygen · Carbon dynamics

\section{INTRODUCTION}

The coastal zone covers an area of $26 \times 10^{6} \mathrm{~km}^{2}(7 \%$ of the surface of the global ocean) and is one of the most biogeochemically active regions of the biosphere (Gattuso et al. 1998). Although it comprises 30 to $50 \%$ of calcium carbonate and about $80 \%$ of organic carbon accumulation of the whole ocean (Wollast \& Mackenzie 1989, Morse \& Mackenzie 1990, Wollast 1991, 1998, Milliman 1993, Smith \& Hollibaugh 1993), there is no consensus on whether the coastal ocean acts as a net source or sink for atmospheric carbon dioxide $\left(\mathrm{CO}_{2}\right.$; Borges 2005). This depends mainly on 2 major processes: organic matter production/mineralization and calcium carbonate $\left(\mathrm{CaCO}_{3}\right)$ precipitation/dissolution. Indeed, $\mathrm{CO}_{2}$ is released during organic matter production and $\mathrm{CaCO}_{3}$ precipitation (Wollast et al. 1980), while primary production and $\mathrm{CaCO}_{3}$ dissolution are $\mathrm{CO}_{2}$-consuming processes. Two major reasons can explain the lack of consensus on the role of the coastal 
ocean in the global carbon cycle: (1) the net ecosystem production (NEP), defined as the difference between organic matter production and mineralization in an ecosystem, and net calcification, defined as the difference between calcium carbonate precipitation and dissolution, are still poorly documented and (2) the large physiographic and environmental diversity of coastal ecosystems complicates any upscaling procedure (Gazeau et al. 2004).

Estuaries are particularly complex cases of coastal ecosystems, as they are inherently variable and dynamic with large temporal (from daily to seasonal time scales) and spatial gradients (Heip et al. 1995). Thus, to estimate the metabolic status of such systems a fully integrated method both in space and time is required.

An ecosystem is deemed net autotrophic when production of organic matter by primary producers exceeds the consumption of this matter by both autotrophic and heterotrophic organisms. Such systems are potentially net sinks for atmospheric $\mathrm{CO}_{2}$, although import of water with a high partial pressure of $\mathrm{CO}_{2}\left(\mathrm{pCO}_{2}\right)$, such as in productive upwelling areas or estuaries, can result in the release of $\mathrm{CO}_{2}$ to the atmosphere (Gattuso et al. 1998). By contrast, an ecosystem is heterotrophic when consumption exceeds gross primary production, leading generally to high $\mathrm{pCO}_{2}$ and low oxygen $\left(\mathrm{O}_{2}\right)$ concentrations in the water column.

A wide range of techniques has been used to estimate the metabolic status of coastal ecosystems. Each technique relies on one or several assumptions and covers different spatial and temporal scales. For instance, metabolic process rate measurements based on incubation methods (mainly $\mathrm{O}_{2}$ and ${ }^{14} \mathrm{C}$ ) or openwater $\mathrm{O}_{2}$ measurements (Odum 1956, Kemp \& Boynton 1980, Howarth et al. 1992, Caffrey 2004) have been used on local scales in numerous studies, but their extrapolation to larger areas remains problematic.

The direct measurement of $\mathrm{CO}_{2}$ fluxes across the air-water interface has been only recently applied at large spatial and temporal scales in a number of coastal ecosystems (Frankignoulle et al. 1998, Tsunogai et al. 1999, Cai et al. 2000, Raymond et al. 2000, Frankignoulle \& Borges 2001b, Borges \& Frankignoulle 2002, Borges 2005, Hales et al. 2005).

Within the International Geosphere-Biosphere Program (IGBP), the Land Ocean Interaction in the Coastal Zone (LOICZ) stoichiometry budgeting approach has been applied to more than 170 sites and can provide system-scale estimates (Gordon et al. 1996). This method is based on the estimation of NEP from non-conservative fluxes of either dissolved inorganic carbon (DIC) or dissolved inorganic phosphorus (DIP).
In order to assess the metabolic status of the coastal zone on a global scale, there is a great need to perform estimates on a wide range of ecosystems. As mentioned above, several techniques are available for such an objective, but very few studies have focused on comparing different methods (Kemp et al. 1997) and testing their validity in a variety of ecosystem types.

The purpose of the EUROTROPH project (www.ulg. ac.be/oceanbio/eurotroph/) was to determine the metabolic status of 3 European coastal ecosystems (Randers Fjord, Scheldt estuary and Bay of Palma) using several techniques and to compare the estimates at several time scales. Here, we estimate the metabolic status of the Randers Fjord (Denmark) during 2 field studies in 2001 (April and August). The following methods were used and compared: integration and extrapolation of changes in $\mathrm{O}_{2}$ during incubations, dissolved inorganic carbon (DIC) budgets, the RSD (response surface difference) method based on diel $\mathrm{O}_{2}$ changes and LOICZ biogeochemical budgets.

\section{MATERIALS AND METHODS}

Study area. Randers Fjord is the longest Danish estuary located on the east coast (Fig. 1). The river and fjord drain an area of $3260 \mathrm{~km}^{2}$ and receive treated sewage water from 600000 inhabitants. The estuary is $27 \mathrm{~km}$ long and covers an area of $23 \mathrm{~km}^{2}$. The main freshwater input comes from the river Gudenå, which drains $80 \%$ of the catchment area and enters the innermost part of Randers Fjord (Nielsen et al. 2001); the tidal range is small $(0.2$ to $0.3 \mathrm{~m})$ and highest in the inner estuary (Nielsen et al. 2001). The mean annual water residence time within the estuary is $\sim 13 \mathrm{~d}$ (Nielsen et al. 2001). A pycnocline is present throughout the year in almost the entire estuary (Nielsen et al. 1993). The top layer of sediment varies from soft mud with a high organic content (10 to $14 \%$ ignition loss) in the inner part to fine/medium-sized silt with low organic content ( 1 to $2 \%$ ignition loss) in the outer area (Nielsen et al. 2001). Seasonal anoxic conditions in bottom waters have been reported in the innermost part of the estuary during summer (Sømod et al. 1999). In the 1970 s, regulatory measures were implemented in order to decrease the loading of nutrients and organic carbon from point sources and cities. Additionally, villages with more than 200 inhabitants were required to build sewage treatment plants with $\mathrm{C}, \mathrm{N}$ and $\mathrm{P}$ removal capabilities.

Experimental schedule. The metabolic performance of the Randers Fjord was estimated during 2 field cruises in April to May 2001 (referred hereafter as the April campaign: 22 April to 2 May) and August (20 to 31 August) 2001 by means of $\mathrm{O}_{2}$ incubations, DIC, RSD 
and LOICZ approaches. $\mathrm{O}_{2}$ incubation and RSD methods considered the estuary from Stn 6 to the mouth (Fig. 1), while the DIC and LOICZ budgeting procedures used data from Stn 6 as external (riverine) conditions and therefore covered an area from downstream to this station to the mouth of the estuary. Temporal scales encompassed by the different methods as well as sampling dates are shown in Fig. 2. The RSD method was applied during 1 day at each period, while other methods covered several days. Note that the DIC method was only applied to the mixed layer of this estuary (see below).

Oxygen incubations. Planktonic gross primary production (GPP) and community respiration (CR) were measured at several stations (on different days; see Fig. 2) in the estuary during the 2 cruises (Stns 1a, 2, 2a, 5 and 6 in April; Stns 2, 4, 4a, 5 and 6 in August; Fig. 1). Samples were taken and incubated in situ at 4 depths (see Table 1; 5 replicates at each depth) from sunrise to sunset in both transparent and dark $60 \mathrm{ml}$ biochemical oxygen demand (BOD) bottles. $\mathrm{O}_{2}$ concentrations were measured before and after incubation using an automated Winkler titration technique with a potentiometric end-point detection. Analyses were performed with an Orion redox electrode (9778-SC) and a custom-built titrator. Reagents and standardizations were similar to those described by Knap et al. (1996). Hourly planktonic CR (expressed as a negative value) and hourly net community production during the day $\left(\mathrm{NCP}_{\mathrm{d}}\right)$ were estimated as the difference between the $\mathrm{O}_{2}$ concentration at the end and the beginning of the incubations divided by the time of incubation, in the dark and transparent bottles, respectively. Hourly planktonic GPP was calculated as the difference between $\mathrm{NCP}_{\mathrm{d}}$ and $\mathrm{CR}$.

Triplicate sediment cores (diameter $=8 \mathrm{~cm}$ ) were collected with a box corer at 5 stations along the estuary in the navigation channel. Additionally, 2 sets of triplicate sediment cores were collected manually at 3 stations located on the shallow banks (Fig. 1). Cores collected in the navigation channel and one set of cores from the banks were incubated in the laboratory at in situ temperature in darkness for around $6 h_{\text {; the other }}$ set of bank cores was incubated outside the laboratory under in situ light conditions for 3 to $6 \mathrm{~h}$. Before the start of the incubations, the overlying water was removed and cores were filled with in situ water (height $=0.2 \mathrm{~m}$ ). Cores were closed with airtight lids carefully to avoid trapping air bubbles. The overlying water was stirred during the whole incubation period, avoiding sediment perturbation. Water samples were collected with syringes before and after incubation, and $\mathrm{O}_{2}$ concentrations were determined by the Winkler method using potentiometric end-point detection and a Mettler titrator (DL21). Hourly benthic CR and GPP rates were calculated with the same method as that for the planktonic compartment outlined above.

Daily planktonic and benthic CR were calculated by multiplying the hourly rates by 24 . Hourly GPP rates were multiplied by the daylight duration (14 and $15 \mathrm{~h}$ in April and August, respectively) to estimate daily planktonic and benthic GPP.

At each station and incubation depth, samples were taken for chlorophyll $a$ and nutrient analysis. For chlorophyll a determination, water (1000 to $1500 \mathrm{ml}$ ) was filtered through GF/F filters, which were stored frozen pending pigment extraction and analysis by high-performance liquid chromatography (Barranguet et al. 1997). Automated colorimetric techniques were used for orthophosphate, nitrate, nitrite and ammonium (Van den Meersche et al. 2004).

Light penetration in the water column was measured using an LI-COR spherical sensor (LI-193SA) and a datalogger (LI-1400) twice during each incubation period. Surface irradiance was measured every $15 \mathrm{~min}$ during the first cruise using an LI-COR cosine corrected sensor (LI-192SA) and a datalogger (LI-1400). Hourly surface irradiance data during the second cruise measured at Folum, about $25 \mathrm{~km}$ from the city of Randers, were provided by the Danish Institute of 
Agricultural Sciences. Light attenuation in the water column was estimated using the formulation:

$$
K=-\frac{\ln \left(I_{z} / I_{0}\right)}{Z}
$$

where $K$ is the light attenuation coefficient $\left(\mathrm{m}^{-1}\right), I_{z}$ is the irradiance measured at depth $z$ ( $\mu \mathrm{mol}$ photons $\left.\mathrm{m}^{-2} \mathrm{~s}^{-1}\right)$,
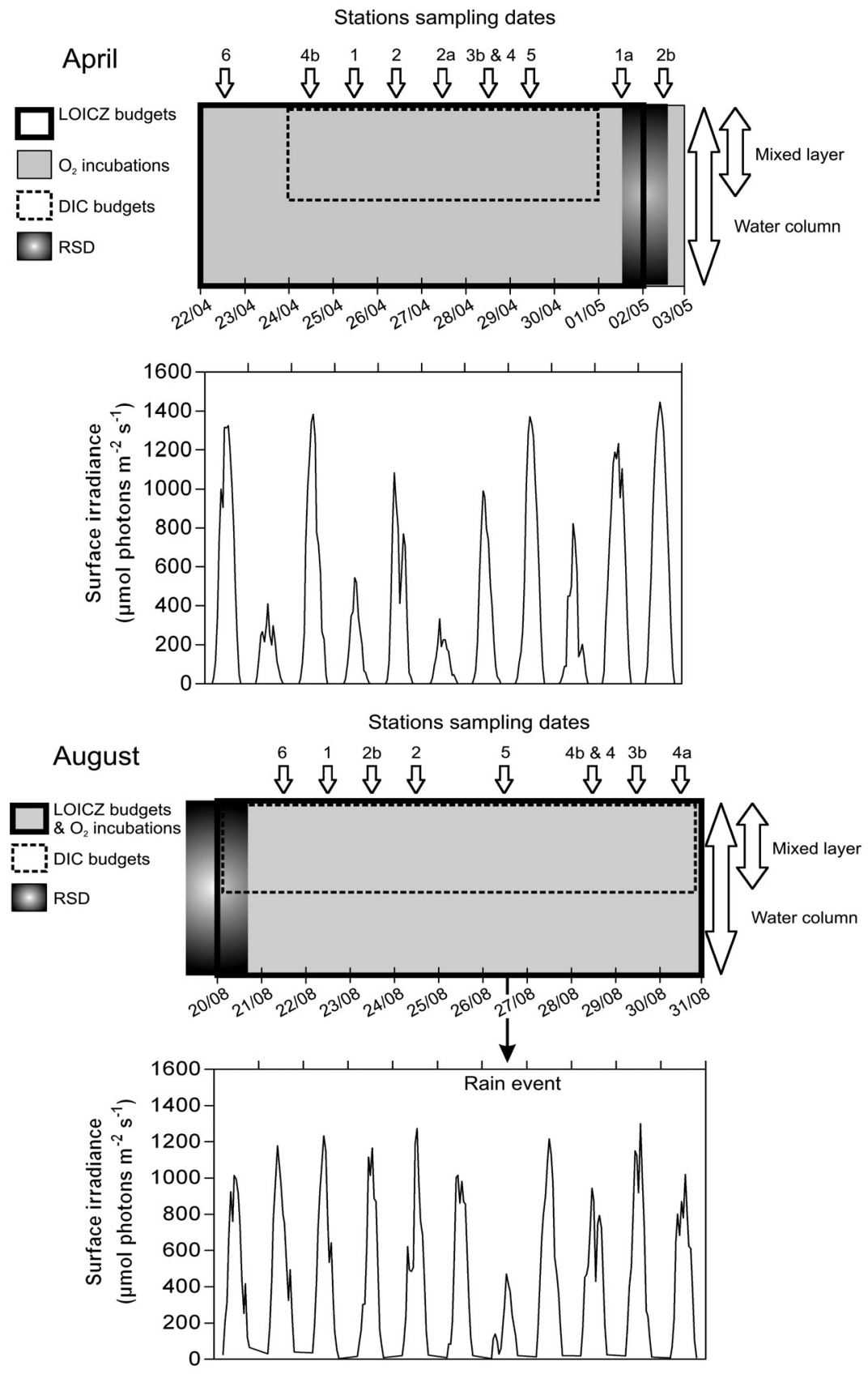

Fig. 2. Schedule of measurements using the different methods considered in this study during the 2 cruises (see Fig. 1). Stations where $\mathrm{O}_{2}$ incubations (both planktonic and benthic) as well as dissolved inorganic phosphorus (DIP) measurements (LOICZ method) were performed are also presented. Surface irradiance variations over the course of the 2 cruises are shown. Dates are $d / m o$
$I_{0}$ is surface irradiance ( $\mu \mathrm{mol}$ photons $\mathrm{m}^{-2} \mathrm{~s}^{-1}$ ) and $z$ is depth $(\mathrm{m})$.

Primary production is largely dependent on irradiance, and since (1) samples for benthic GPP measurements were taken at only one depth with incubations performed under a $0.2 \mathrm{~m}$ water height and (2) incubations were conducted for only 3 to $6 \mathrm{~h}$ around noon, a procedure to extrapolate these data to the whole depth gradient and to the whole day length was used. During both cruises, relationships between daily benthic GPP rates (GPP, $\mathrm{mmol} \mathrm{O}_{2} \mathrm{~m}^{-2} \mathrm{~d}^{-1}$ ) and average irradiance $(I)$ during incubations were derived for each station using the model of Platt et al. (1980):

$$
\mathrm{GPP}=\mathrm{GPP}_{\max }\left[1-\exp \left(-I / I_{k}\right)\right]
$$

where $\mathrm{GPP}_{\max }$ is the maximal GPP rate $\left(\mathrm{mmol} \mathrm{O} \mathrm{O}^{-2} \mathrm{~d}^{-1}\right), I_{\mathrm{k}}$ is the irradiance at which the initial slope and GPP $_{\max }$ intersect ( $\mu \mathrm{mol}$ photons $\mathrm{m}^{-2} \mathrm{~s}^{-1}$ ), estimated from irradiance and light attenuation coefficients. Gargas (1970) estimated saturation irradiance $\left(I_{k}\right)$ on an annual scale in sediments of Nivå bay (Oresund) and reported values of around 100 and $300 \mu \mathrm{mol}$ photons $\mathrm{m}^{-2} \mathrm{~s}^{-1}$ in April and August, respectively. Thus, for each station we adopted these parameters and calculated GPP $\max _{\max }\left(\mathrm{mmol} \mathrm{O}_{2} \mathrm{~m}^{-2} \mathrm{~d}^{-1}\right)$ values to fit our data using Eq. (2). This procedure allowed us to estimate GPP during the daylight duration and to account for the decrease of benthic GPP with depth.

The fjord was divided into 2 boxes (inner and outer boxes, see Fig. 1), and 3 depth intervals were considered $(0-2 \mathrm{~m}$, 2-4 $\mathrm{m}$ and 4-7 $\mathrm{m}$, the latter corresponding to the navigation channel). The surface area and the percentage covered by each depth layer were estimated at each sampling station using a digitized map (INT 1381) and Arcview 8.3 software package.

Planktonic volumetric rates (GPP and $\mathrm{CR}$ ) were depth-integrated using a simple trapezoidal procedure over the 3 depth intervals. Using Eq. (2), benthic GPP collected on the banks were extrapolated over 0 and $2 \mathrm{~m}$ and either 0 and $4 \mathrm{~m}$ or 0 and the depth of the euphotic zone when this latter was less than $4 \mathrm{~m}$. Benthic CR measured on the banks were assumed to represent the first 2 depth intervals, while benthic $\mathrm{CR}$ measured in the navigation 
channel were used for the 0-7 $\mathrm{m}$ depth interval. Weighted averages of both planktonic (integrated) and benthic rates were estimated for each station according to the bathymetric profile. It must be stressed that benthic GPP was assumed to be nil in the inner box of the estuary (where no measurements were performed) that mainly consists of the navigation channel (depth = $7 \mathrm{~m}$ ) with a negligible surface area covered by banks. Finally, these planktonic and benthic metabolic rates were simply averaged to estimate metabolic rates in the 2 boxes considered.

Planktonic and benthic metabolic rates were converted to carbon units assuming a photosynthetic quotient (PQ) of 1.3 based on the C:N:P molar elemental composition of phytoplankton reported by Redfield (1963) and a respiratory quotient (RQ) of 1 as used in most studies (Hopkinson \& Smith 2005). Daily planktonic and benthic NCP were calculated as the sum of daily GPP and CR, and the net ecosystem production (NEP) of each box was estimated by summing benthic and planktonic NCP rates.

Dissolved inorganic carbon (DIC) budgets. In April, subsurface $(0.5 \mathrm{~m}) \mathrm{pCO}_{2}$, total alkalinity (TA) and $\mathrm{O}_{2}$ data were obtained at 2 stations which were occupied during $24 \mathrm{~h}$ (Stns 2 and 4, respectively, on 25-26 and 28-29 April 2001) and along a transect aboard the Genetica from the city of Randers to the mouth of the estuary (30 April 2001). In August, the same variables were obtained at 3 stations occupied during $24 \mathrm{~h}$ (Stns 2, 4 and 6, respectively, on 23-24, 27-28 and 20-21 August 2001) and along 2 transects aboard the Tyrfing from the city of Randers to the mouth of the estuary on 30 and 31 August 2001. Samples for TA and $\mathrm{O}_{2}$ were collected hourly during the $24 \mathrm{~h}$ cycles and every 2 salinity units during the shipboard transects. Samples for TA determination were filtered using $\mathrm{GF} / \mathrm{F}$ filters.

$\mathrm{pCO}_{2}$ was measured every minute by equilibration using the Floating Equilibrator System (FES) described by Frankignoulle et al. (2003). Briefly, the FES is a buoy containing an equilibrator, a non-dispersive infrared gas analyser (IRGA), water and air temperature probes, an anemometer, a datalogger (1 min recording interval) and air and water pumps. During the $24 \mathrm{~h}$ cycles, the FES was deployed and anchored before 12:00 h UT (Universal Time). For the shipboard transects, it was adapted for underway measurements from the subsurface water supply of the ship. The IRGA (LICOR 6262) was calibrated daily using pure nitrogen and 3 gas standards with a $\mathrm{CO}_{2}$ molar fraction of 365 , 810 and $4000 \mathrm{ppm}$. All gases were supplied by Air Liquide, Belgium. The estimated accuracy of the $\mathrm{pCO}_{2}$ measurements is $\pm 3 \mathrm{ppm}$. $\mathrm{pCO}_{2}$ in the air was measured using a non-dispersive infrared gas analyser (IRGA) during the $24 \mathrm{~h}$ cycles at the start of each float- ing dome measurement, carried out hourly, to estimate the gas transfer velocity (Borges et al. 2004). TA was measured by Gran electro-titration on $100 \mathrm{ml}$ samples with a reproducibility of $\pm 2 \mu \mathrm{mol} \mathrm{\textrm {kg } ^ { - 1 }}$ and an esti-

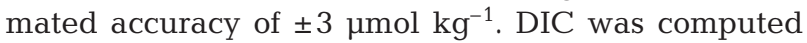
from $\mathrm{pCO}_{2}$ and TA (acquired during the transects and the $24 \mathrm{~h}$ cycles) using the thermodynamic constants of Mehrbach et al. (1973); the accuracy is $\pm 5 \mu \mathrm{mol} \mathrm{kg}{ }^{-1}$ (for further details refer to Frankignoulle \& Borges 2001a). $\mathrm{O}_{2}$ was measured by the Winkler method using a potentiometric end-point determination, with an estimated accuracy of $\pm 2 \mu \mathrm{mol} \mathrm{kg} \mathrm{kg}^{-1}$. Salinity was measured with a portable salinometer (Orion 125) with a precision of \pm 0.1 .

A mass balance of DIC in the mixed layer was constructed using estimates of fluvial DIC input, output of DIC to the Baltic Sea and air-water $\mathrm{CO}_{2}$ flux. NEP was computed to balance the budget. The fluvial DIC input

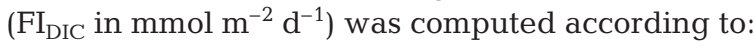

$$
\mathrm{FI}_{\mathrm{DIC}}=\frac{\rho \mathrm{DIC} Q}{S}
$$

where $\mathrm{DIC}_{0}$ is the mean value of DIC measured at Stn $6\left(\mathrm{mmol} \mathrm{kg}^{-1}\right), \rho$ is the water density $\left(\mathrm{kg} \mathrm{m}^{-3}\right), Q$ is the average freshwater flow during each campaign $\left(\mathrm{m}^{3} \mathrm{~d}^{-1}\right)$ and $S$ is the surface area of the Fjord $\left(\mathrm{m}^{2}\right)$. The output of DIC to the Baltic Sea $\left(\mathrm{OBS}_{\mathrm{DIC}}\right.$ in $\mathrm{mmol} \mathrm{m} \mathrm{m}^{-2}$ $\mathrm{d}^{-1}$ ) was computed according to:

$$
\mathrm{OBS}_{\mathrm{DIC}}=\frac{\rho \mathrm{DIC}}{\mathrm{AZE} Q}
$$

where $\mathrm{DIC}_{\mathrm{AZE}}$ is the apparent zero end-member of DIC $\left(\mathrm{mmol} \mathrm{kg} \mathrm{kg}^{-1}\right), \rho$ is water density $\left(\mathrm{kg} \mathrm{m}^{-3}\right), Q$ is the average freshwater flow during each campaign $\left(\mathrm{m}^{3} \mathrm{~d}^{-1}\right)$ and $S$ is the surface area of the Fjord $\left(\mathrm{m}^{2}\right)$. Data of freshwater flows during the investigated periods were provided by the National Environmental Research Institute, Department of Freshwater Ecology, Denmark. DIC $\mathrm{AZE}$ is the intercept at zero salinity of a line tangent to the observed curve of DIC (from transects and $24 \mathrm{~h}$ cycles) against salinity in the lower estuary (Kaul \& Froelich 1984). The intercept at zero salinity was computed by linear regression from DIC data at salinities above 9, since DIC showed a close to conservative behaviour in the lower estuary.

The air-water $\mathrm{CO}_{2}$ flux was computed according to:

$$
F=\alpha k \Delta \mathrm{pCO}_{2}
$$

where $F$ is the air-water $\mathrm{CO}_{2}$ flux $\left(\mathrm{mmol} \mathrm{m} \mathrm{m}^{-2} \mathrm{~d}^{-1}\right)$, $\alpha$ is the $\mathrm{CO}_{2}$ solubility coefficient $\left(\mathrm{mmol} \mathrm{m} \mathrm{mpm}^{-1}\right), k$ is the gas transfer velocity $\left(\mathrm{m} \mathrm{d}^{-1}\right)$ and $\Delta \mathrm{pCO}_{2}$ is the air-water gradient of $\mathrm{CO}_{2}\left(\mathrm{pCO}_{2 a i r}-\mathrm{pCO}_{2 \text { water }}\right.$ in $\left.\mathrm{ppm}\right)$. The $\mathrm{CO}_{2}$ solubility coefficient $(\alpha)$, dependent upon salinity and temperature, was computed according to 
Weiss (1974). The averaged atmospheric $\mathrm{pCO}_{2}$ was estimated for each cruise as its variability is negligible compared to the range of variation of $\mathrm{pCO}_{2}$ in the water. A positive flux corresponds to a transfer of $\mathrm{CO}_{2}$ from the water to the atmosphere. We estimated the flux of $\mathrm{CO}_{2}$ in the inner box (from downstream to Stn 6 to Stn 5 using this method) and in the outer box (see Fig. 1) and computed a weighted average value for the whole estuary considering the surface area covered by these 2 boxes.

The gas transfer velocity was computed according to a parameterization as a function of wind speed established from floating chamber interfacial $\mathrm{CO}_{2}$ flux measurements carried out during the 2 cruises (Borges et al. 2004):

$$
k_{600}=0.3( \pm 0.2)+0.536( \pm 0.026) u_{10}
$$

where $k_{600}\left(\mathrm{~m} \mathrm{~d}^{-1}\right)$ is the gas transfer velocity of $\mathrm{CO}_{2}$ normalized to a Schmidt number $(S C)$ of 600 and $u_{10}$ is wind speed referenced at a height of $10 \mathrm{~m}\left(\mathrm{~m} \mathrm{~s}^{-1}\right) \cdot k_{600}$ was converted to in situ temperature conditions assuming a $k$ dependency proportional to $S C^{-0.5}$ :

$$
k=k_{600} \cdot\left(\frac{S C}{600}\right)^{-0.5}
$$

$S C$ was computed for a given salinity and temperature from the formulations for salinity 0 and 35 given by Wanninkhof (1992) and assuming that $S_{C}$ varies linearly with salinity.

Response surface difference (RSD) method. The RSD method developed by Swaney et al. (1999) is derived from the in situ diel $\mathrm{O}_{2}$ approach applied to flowing waters. It is based on the comparison of $\mathrm{O}_{2}$ concentrations at an initial time and station with $\mathrm{O}_{2}$ concentrations at a second station downstream, after the time interval estimated for water to flow from the upstream to the downstream station (Odum 1956). In tidal estuarine systems, this procedure is difficult to apply because of non-unidirectional flows and of the intrusion of marine waters resulting in water column stratification. Swaney et al. (1999) used in their method salinity as a conservative tracer to provide information on mixing and advection. This procedure is based on the hypothesis that the concentration of $\mathrm{O}_{2}$ in an estuary varies linearly with depth, salinity and time, following the equation:

$$
\mathrm{O}_{2}=b_{0}+b_{z} z+b_{s a l} S a l+b_{t} t+\varepsilon
$$

where $\mathrm{O}_{2}$ is the observed $\mathrm{O}_{2}$ concentration $\left(\mathrm{mmol} \mathrm{m}^{-3}\right)$, $b_{0}$ is the rate of $\mathrm{O}_{2}$ concentration variation associated with a unit change in each of the independent variables $(z=$ depth in $\mathrm{m}, S a l=$ salinity and $t=$ time in hours), and $\varepsilon$ represents the random component of $\mathrm{O}_{2}$ concentration variation not explained by the independent variables.
In April, 8 stations were investigated along the estuary (Stns 1a, 2, 2a, 3, 4, 5, 5a and 6; see Fig. 1) at midday, sunset (1 May 2001) and sunrise (2 May 2001). Seven stations were investigated in August (Stns 2, 2a, 3, 4, 5, 5a and 6; see Fig. 1) at sunset (19 August 2001), sunrise, midday and sunset (20 August 2001). At each station, vertical profiles of $\mathrm{O}_{2}$, temperature and salinity were made using a YSI 556 multiprobe. The $\mathrm{O}_{2}$ sensor was calibrated in water-saturated air before each transect. Wind speed was measured with a hand-held anemometer.

The variation of oxygen over time during the day $\left(b_{t \_\mathrm{d}}\right.$ in mmol $\mathrm{O}_{2} \mathrm{~m}^{-3} \mathrm{~h}^{-1}$ ) was then estimated by means of a multiple regression following Eq. (8), using data acquired at midday and at sunset in April and at sunrise, midday and sunset in August. The same procedure was used to estimate the variation of oxygen over time during the night $\left(b_{t \_n}\right)$ by considering data acquired at sunset and sunrise in April and August (first sunset). The same division of the estuary was used as for the $\mathrm{O}_{2}$ incubation method, and computations of metabolic parameters were performed for the inner and outer boxes as well as the whole estuary.

Hourly depth-integrated NEP during the day $\left(\mathrm{NEP}_{\mathrm{d}}\right)$ was estimated as:

$$
\mathrm{NEP}_{\mathrm{d}}=b_{t \_\mathrm{d}} z+F_{\mathrm{O}_{2 \_} \mathrm{d}}
$$

where $z$ is the mean depth of the estuary $(1.6 \mathrm{~m})$ and $F_{\mathrm{O}_{2} \mathrm{~d}}$ is the estimated air-water $\mathrm{O}_{2}$ exchange during the day in $\mathrm{mmol} \mathrm{O}_{2} \mathrm{~m}^{-2} \mathrm{~h}^{-1}$.

Hourly depth-integrated CR was estimated from the $\mathrm{O}_{2}$ decrease overnight:

$$
\mathrm{CR}=b_{\mathrm{t} \_\mathrm{n}} z+F_{\mathrm{O}_{2 \_} \mathrm{n}}
$$

where $z$ is the mean depth of the estuary $(1.6 \mathrm{~m})$ and $F_{\mathrm{O}_{2} \mathrm{n}}$ is the estimated air-water $\mathrm{O}_{2}$ exchange during the night in $\mathrm{mmol} \mathrm{O}_{2} \mathrm{~m}^{-2} \mathrm{~h}^{-1}$. Positive $\mathrm{O}_{2}$ fluxes correspond to a transfer from the water to the atmosphere.

The air-water $\mathrm{O}_{2}$ fluxes, at each investigated station, during the day and night, were computed using wind speed values measured during the transects, the same procedure as described for $\mathrm{CO}_{2}$ fluxes (Eq. 5 above) as well as an $\mathrm{O}_{2}$ solubility coefficient and an $\mathrm{O}_{2}$ concentration at saturation $\left(\mathrm{O}_{2 \text { air }}\right)$ computed according to Benson \& Krause (1984). These air-water $\mathrm{O}_{2}$ fluxes estimated at each sampled station, during the day and night, were then averaged over the investigated area (inner, outer and whole estuary). Hourly GPP was calculated as the difference between hourly $\mathrm{NCP}_{\mathrm{d}}$ and CR. Computations of daily rates as well as conversions to carbon units were performed as previously described in the section on oxygen incubation.

LOICZ budgeting procedure. Stoichiometrically linked water-salt-nutrient budgets were constructed 
using data collected during the 2 cruises as described by Gordon et al. (1996). A 2 box-2 layer model was considered, as strong vertical stratifications were observed in the fjord. We considered the same division of the estuary as that used with the previous methods (inner and outer box, see Fig. 1), although, as was already mentioned, the inner box covered the area downstream to Stn 6. The depth of the mixed layer was estimated for each sampled station using data of salinity and temperature. Data of freshwater flows during the periods investigated were provided by the National Environmental Research Institute, Department of Freshwater Ecology, Denmark. Vertical profiles (4 depths, same as $\mathrm{O}_{2}$ incubation depths) of salinity and DIP were performed at the beginning of each $\mathrm{O}_{2}$ incubation experiment as described above (Stns 1a, 2, 2a, 5 and 6 in April; Stns 2, 4, 4a, 5 and 6 in August). Vertical profiles acquired at Stns 1 and 6 during both cruises were used as marine and riverine end-members, respectively. Salinity and DIP concentrations in each budgeted box were estimated by averaging data in the vertical and horizontal dimensions.

Residual and exchange water fluxes (Fig. 3) between each box and between the estuary and the Kattegat were estimated from freshwater flow and salinity (conservative parameter), considering that over a tidal cycle salinity is at steady state:

$$
\left(\frac{\mathrm{d} S a l}{\mathrm{~d} t}=0\right)
$$

Stn. 6

Stn. 5 in each compartment (see Gordon et al. 1996 and LOICZ biogeochemical modeling Web site at http:// data.ecology.su.se/MNODE/Methods/TOC.HTM for details of the calculations). Applying these residual and exchange fluxes to a parameter which can be influenced by biotic or abiotic processes (non-conservative parameter) allows the estimation of non-conservative fluxes in each budgeted box (basically, deviation from the dilution/mixing line).

NEP (p-r in LOICZ terminology) was calculated from the non-conservative fluxes of DIP in each box, assuming that (1) these DIP fluxes are only related to biological activity (i.e. organic matter production and mineralization) and (2) dissolved organic phosphorus (DOP) cycling is negligible, following the equation:

$$
\mathrm{NEP}=-\Delta \mathrm{DIP} \cdot(\mathrm{C}: \mathrm{P})_{\text {part }}
$$

where NEP is the net ecosystem production (mmol C $\left.\mathrm{m}^{-2} \mathrm{~d}^{-1}\right), \Delta \mathrm{DIP}$ is the non-conservative flux of DIP $\left(\mathrm{mmol} \mathrm{P} \mathrm{m} \mathrm{m}^{-2} \mathrm{~d}^{-1}\right.$ ) and $(\mathrm{C}: \mathrm{P})_{\text {part }}$ is the particulate $\mathrm{C}: \mathrm{P}$ ratio. As no information on the composition of organic matter was available for this system, a value of 106:1 (Redfield ratio) was assumed. Then, a system with $\Delta \mathrm{DIP}>0$ is interpreted as producing DIP via net organic matter mineralization (NEP $<0$ ), while a negative $\Delta \mathrm{DIP}$ is related to an organic matter production in excess (NEP > 0).

Error estimates. Error propagations for each method described above were performed using the Monte Carlo procedure in Matlab 6.5. Each parameter was changed within reasonable boundaries (95\% confi-

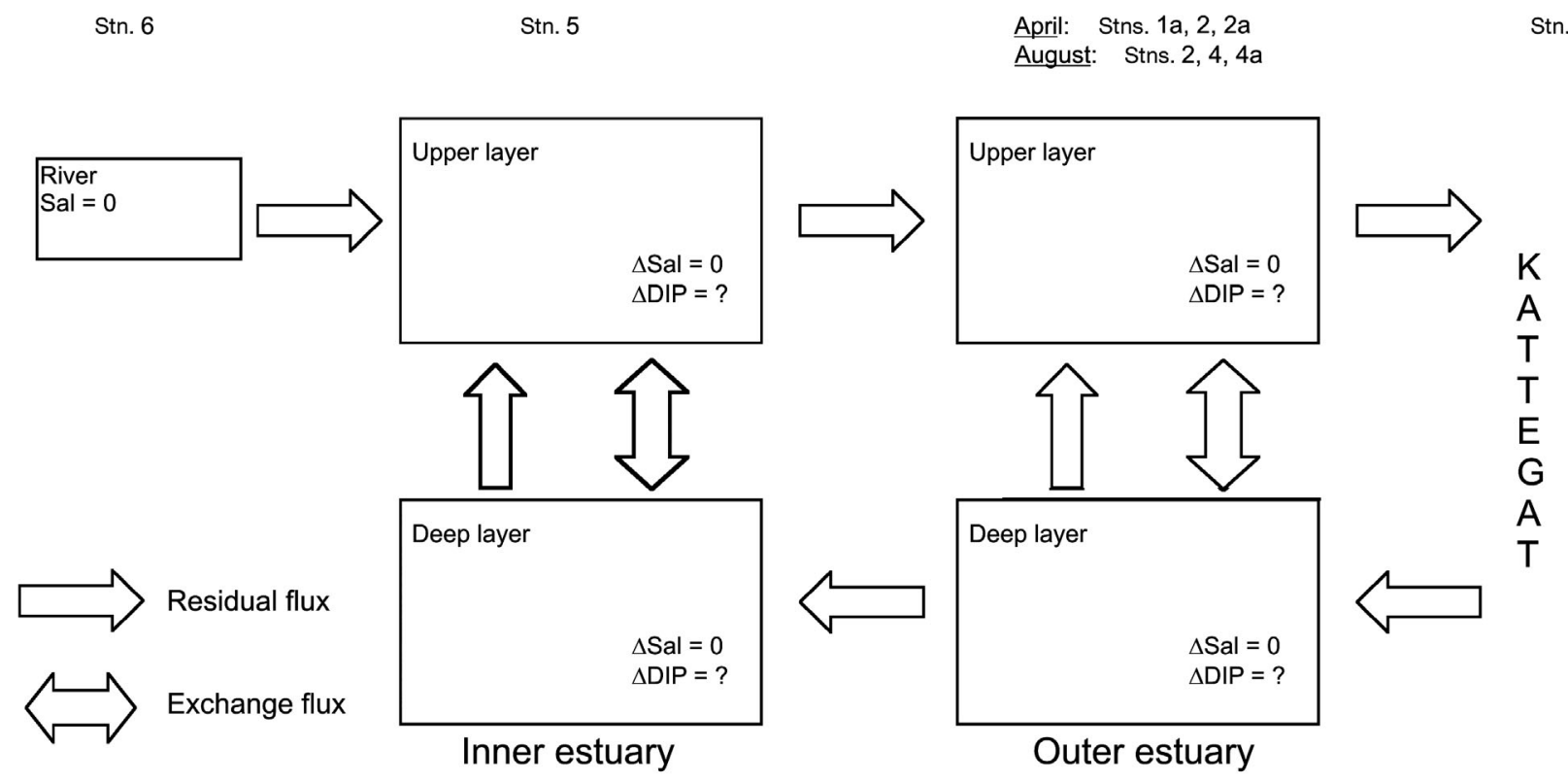

Fig. 3. Land-Ocean Interaction in the Coastal Zone (LOICZ) budgeting procedure for the Randers Fjord during the 2 cruises. Data of salinity and dissolved inorganic phosphorus (DIP) concentrations at Stns 6 and 1 were used as riverine and marine endmembers, respectively. See Gordon et al. (1996) for calculations details 
dence interval in case of averaged values), and a thousand iterations were performed.

Using the $\mathrm{O}_{2}$ incubation method, analytical and replication errors ( 5 and 3 replicates in the planktonic and benthic compartment respectively, see above) and errors attributed to the averaging of several stations to compute rates for the inner, outer and whole estuary were considered.

Using the DIC method, the uncertainty on the DIC fluvial input was estimated assuming an analytical error on $\mathrm{DIC}_{0}$ of $\pm 0.005 \mathrm{mmol} \mathrm{kg}^{-1}$ and an error on $Q$ of $\pm 5 \%$. Uncertainty on the DIC output to the Baltic Sea was estimated from the standard error on the $y$-intercept of the regression line of DIC vs. salinity $\left(\mathrm{DIC}_{\mathrm{AZE}}\right)$ and assuming an error on $Q$ of $\pm 5 \%$. Uncertainty on the $\mathrm{CO}_{2}$ atmospheric flux was computed assuming an error on $\Delta \mathrm{pCO}_{2}$ of $\pm 3 \mathrm{ppm}$, an error on $u_{10}$ of $\pm 10 \%$ and considering the errors attributed to the parameterization of $k_{600}$ (see Eq. 6) as well as the errors related to the averaging of the fluxes over space.

For the RSD method, uncertainty of the time-dependent $\mathrm{O}_{2}$ rate of change $\left(b_{t}\right)$ was estimated assuming an error on $\mathrm{O}_{2}$ measurements of $\pm 5 \%$ as well as from the standard error of the multiple regression on this parameter. Moreover, uncertainty on the $\mathrm{O}_{2}$ atmospheric flux was computed assuming an error on $u_{10}$ of $\pm 10 \%$,

Table 1. Date, geographical location and characteristics of incubated stations during both cruises. $I_{0}$ is the average surface irradiance, $K$ is the light attenuation coefficient, SPM is the concentration of suspended particulate matter and chl $a$ is the chlorophyll a concentration

\begin{tabular}{|c|c|c|c|c|c|c|c|c|c|c|c|}
\hline & Stn & $\begin{array}{l}\text { Date } \\
(\mathrm{d} / \mathrm{mo})\end{array}$ & $\underset{{ }^{\circ} \mathrm{E}}{\text { Longitude }}$ & $\begin{array}{l}\text { Latitude } \\
{ }^{\circ} \mathrm{N}\end{array}$ & $\begin{array}{l}\text { Depth } \\
\text { (m) }\end{array}$ & Sal & $\begin{array}{l}\text { Temp } \\
\left({ }^{\circ} \mathrm{C}\right)\end{array}$ & $\begin{array}{c}I_{0}(\mu \mathrm{mol} \\
\left.\text { photons } \mathrm{m}^{-2} \mathrm{~s}^{-1}\right)\end{array}$ & $\begin{array}{c}K \\
\left(\mathrm{~m}^{-1}\right)\end{array}$ & $\begin{array}{c}\mathrm{SPM} \\
\left(\mathrm{g} \mathrm{m}^{-3}\right)\end{array}$ & $\begin{array}{c}\mathrm{Chl} \mathrm{a} \\
\left(\mathrm{mg} \mathrm{m}^{-3}\right)\end{array}$ \\
\hline \multicolumn{12}{|l|}{ April } \\
\hline \multirow[t]{12}{*}{ Outer estuary } & $1 \mathrm{a}$ & $1 / 05$ & 10.32 & 56.61 & 0.5 & 12.1 & 9.9 & 737.8 & 0.72 & 5.2 & 1.7 \\
\hline & & & & & 1.5 & 12.3 & 9.9 & & & 3.9 & 1.2 \\
\hline & & & & & 3 & 12.5 & 9.9 & & & 4.0 & 1.1 \\
\hline & & & & & 6 & 19.6 & 9.0 & & & 5.3 & 0.8 \\
\hline & 2 & $26 / 04$ & 10.30 & 56.61 & 0.5 & 6.7 & 8.5 & 472.2 & 0.60 & 5.3 & 1.8 \\
\hline & & & & & 1.5 & 6.8 & 8.5 & & & 5.3 & 2.1 \\
\hline & & & & & 3 & 6.9 & 8.5 & & & 3.9 & 1.5 \\
\hline & & & & & 7 & 29.5 & 7.7 & & & 6.5 & 1.6 \\
\hline & $2 a$ & $28 / 04$ & 10.26 & 56.58 & 0.5 & 4.9 & 8.8 & 454.9 & 0.64 & 43.1 & 6.1 \\
\hline & & & & & 1.5 & 5.3 & 8.9 & & & 5.2 & 4.6 \\
\hline & & & & & 3 & 14.5 & 8.5 & & & 5.8 & 2.1 \\
\hline & & & & & 6 & 19.2 & 8.1 & & & 3.0 & 1.2 \\
\hline \multirow[t]{8}{*}{ Inner estuary } & 5 & $29 / 04$ & 10.21 & 56.47 & 0.5 & 1.4 & 9.1 & 678.2 & 1.13 & 9.7 & 20.9 \\
\hline & & & & & 1.5 & 2.5 & 9.0 & & & 12.4 & 18.3 \\
\hline & & & & & 3 & 14.2 & 8.3 & & & 8.0 & 11.1 \\
\hline & & & & & 6 & 15.9 & 8.2 & & & 35.3 & 9.5 \\
\hline & 6 & $22 / 04$ & 10.04 & 56.46 & 0.5 & 0.2 & 7.0 & 723.2 & 1.28 & 10.2 & 16.0 \\
\hline & & & & & 1 & 0.2 & 7.0 & & & 9.9 & 17.5 \\
\hline & & & & & 1.5 & 0.2 & 7.0 & & & 9.6 & 16.0 \\
\hline & & & & & 4 & 8.2 & 6.6 & & & 9.5 & 7.7 \\
\hline \multicolumn{12}{|l|}{ August } \\
\hline \multirow[t]{12}{*}{ Outer estuary } & 2 & $24 / 08$ & 10.30 & 56.61 & 0.5 & 16.3 & 19.8 & 529.4 & 0.67 & 2.6 & 2.0 \\
\hline & & & & & 1.5 & 18.3 & 19.8 & & & 3.2 & 2.2 \\
\hline & & & & & 3 & 19.8 & 19.8 & & & 2.5 & 2.4 \\
\hline & & & & & 7 & 21.8 & 19.6 & & & 2.4 & 1.5 \\
\hline & 4 & $28 / 08$ & 10.23 & 56.52 & 0.5 & 11.3 & 17.4 & 502.8 & 1.35 & 6.3 & 3.1 \\
\hline & & & & & 1.5 & 11.6 & 17.4 & & & 6.1 & 3.6 \\
\hline & & & & & 3 & 13.6 & 17.8 & & & 7.3 & 3.0 \\
\hline & & & & & 5 & 19.8 & 18.1 & & & 5.1 & 2.2 \\
\hline & $4 a$ & $30 / 08$ & 10.23 & 56.52 & 0.5 & 6.9 & 17.2 & 508.9 & 1.30 & 5.3 & 4.2 \\
\hline & & & & & 1.5 & 8.0 & 17.6 & & & 5.1 & 5.7 \\
\hline & & & & & 3 & 13.2 & 17.1 & & & 4.5 & 4.7 \\
\hline & & & & & 6 & 20.2 & 16.6 & & & 9.4 & 2.7 \\
\hline \multirow[t]{8}{*}{ Inner estuary } & 5 & $26 / 08$ & 10.21 & 56.47 & 0.5 & 2.7 & 19.9 & 183.5 & 0.89 & 3.6 & 3.0 \\
\hline & & & & & 1.5 & 8.7 & 20.3 & & & 3.8 & 2.9 \\
\hline & & & & & 3 & 13.5 & 20.2 & & & 4.6 & 2.7 \\
\hline & & & & & 6 & 16.1 & 20.0 & & & 8.2 & 2.9 \\
\hline & 6 & $21 / 08$ & 10.04 & 56.46 & 0.5 & 0.2 & 18.8 & 588.4 & 0.84 & 4.1 & 4.7 \\
\hline & & & & & 1 & 0.2 & 18.8 & & & 4.5 & 4.7 \\
\hline & & & & & 1.5 & 0.3 & 18.8 & & & 4.1 & 3.8 \\
\hline & & & & & 3.5 & 11.4 & 18.0 & & & 4.9 & 1.8 \\
\hline
\end{tabular}


considering the errors attributed to the parameterization of $k_{600}$ (see Eq. 6) and considering the errors related to the averaging of the fluxes over time and space.

Finally, uncertainty in computed NEP values using the LOICZ procedure was estimated assuming the standard deviation of $Q$ over each campaign duration as well as errors attributed to the averaging over several depths and stations for salinity and DIP values in each budgeted box.

In the following sections, these error estimates will be presented as standard deviations (SD) of all parameters computed using each method. than in the river, suggesting a DIN release in this area. The DIP concentrations were higher in August than in April and were highest in mid-estuary $\left(2.9 \mathrm{mmol} \mathrm{P} \mathrm{m}^{-3}\right.$; Stn 4).

\section{Oxygen incubations}

Rates of planktonic community metabolism (GPP and $\mathrm{CR}$ ) are shown in Table 2. Similar CR volumetric rates were observed in surface waters in April and August ranging from $-1.2 \pm 5.1$ to $-11 \pm 1.9 \mathrm{mmol} \mathrm{C}$

\section{RESULTS}

In April, the mean water temperature was $8.1 \pm 1.0^{\circ} \mathrm{C}$ (Table 1$)$; it was lowest in the freshwater area $\left(\operatorname{Stn} 6 ; 6.6^{\circ} \mathrm{C}\right)$ and highest at the mouth of the estuary (Stn $1 \mathrm{a} ; 9.9^{\circ} \mathrm{C}$ ). In August, the lowest water temperatures were observed mid-estuary (Stns 4 and $4 \mathrm{a}$ ), while the highest values were observed in the inner area (Stn 5), and the mean value during this cruise was $18.5 \pm 1.2^{\circ} \mathrm{C}$. The water column was stratified during both cruises, especially in the inner part of the estuary. In April, the light attenuation coefficient $(K)$ was highest in the inner estuary where relatively high suspended particulate matter (SPM) concentrations were measured. In August, the most turbid waters were located mid-estuary. Large changes of mean surface irradiance were observed during both cruises. The total range was 184 to $738 \mu \mathrm{mol}$ photons $\mathrm{m}^{-2} \mathrm{~s}^{-1}$.

$\mathrm{O}_{2}$ percentage of saturation was higher in April than in August (Fig. 4). The lowest values were measured during both cruises in the inner estuary with a minimal value in August at the bottom of Stn $6(36.8 \%) . \mathrm{O}_{2}$ supersaturations were only measured in the Kattegat (Stn 1) in April. Chlorophyll a concentrations were similar in the outer estuary in April and August with values lower than $3 \mathrm{mg} \mathrm{m}^{-3}$. In the brackish area, values were higher in April than in August with a maximal concentration in surface at Stn 5 (21 $\left.\mathrm{mg} \mathrm{m}^{-3}\right)$.

The DIN concentrations were higher in April than in August with a maximal value in the freshwater area $\left(135 \mathrm{mmol} \mathrm{N} \mathrm{m}^{-3}\right)$. It generally decreased seaward, except in August when surface concentration was higher in the inner part of the estuary (Stn 5)

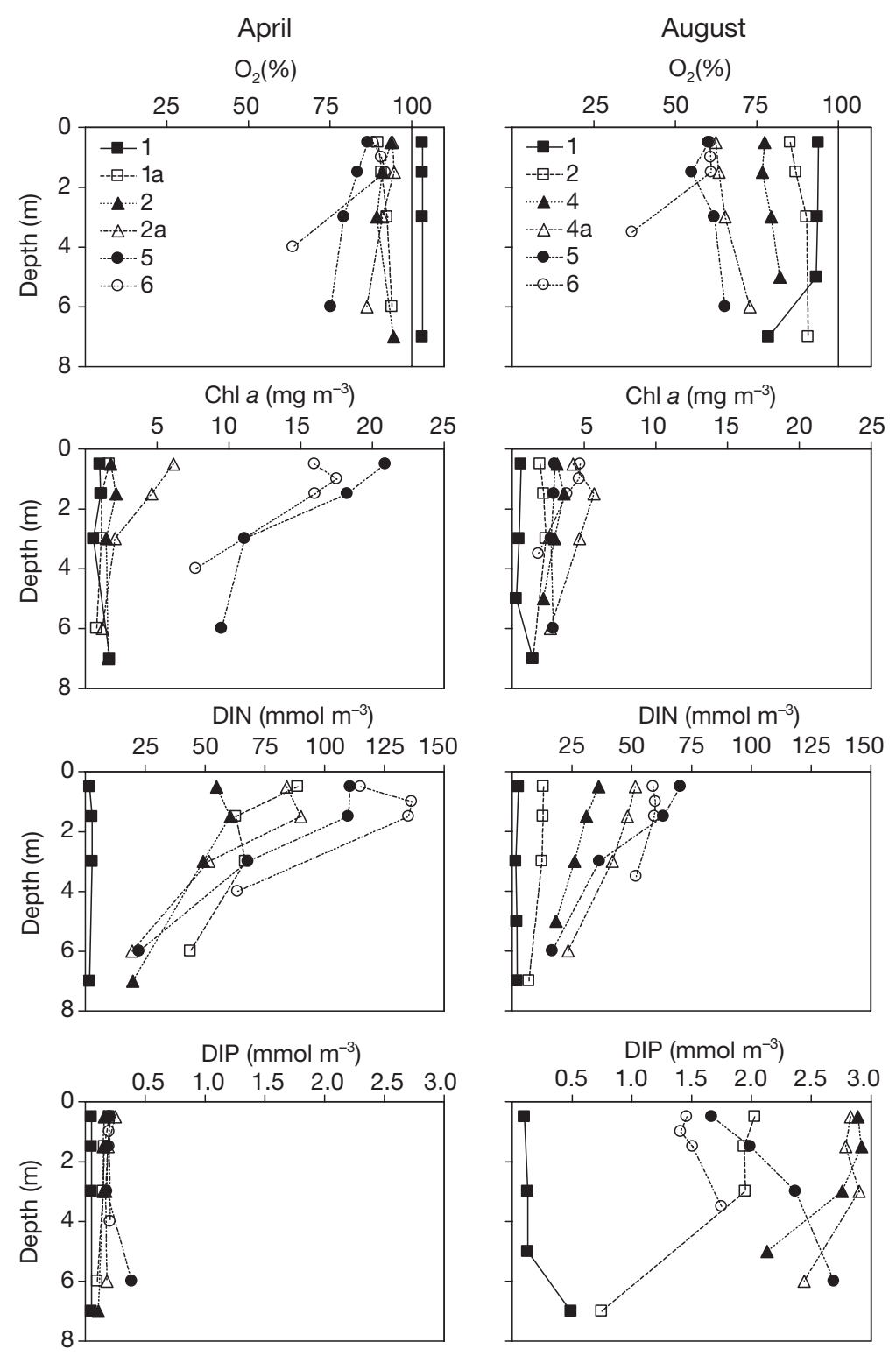

Fig. 4. Vertical profiles of the percentage of oxygen saturation and of the concentrations of chlorophyll a $(\mathrm{chl} a)$, dissolved inorganic nitrogen (DIN) and dissolved inorganic phosphorus (DIP) at each station where incubation of the planktonic community was carried out 
Table 2. Planktonic metabolic rates measured by the oxygen incubation method during both cruises. Rates are expressed

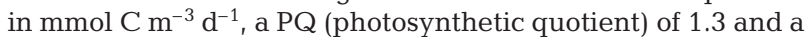
RQ (respiratory quotient) of 1 were assumed to convert $\mathrm{O}_{2}$ rates to carbon units (see text for details). Data are mean $\pm \mathrm{SD}$. GPP: gross primary production; $\mathrm{CR}$ : community respiration

\begin{tabular}{|c|c|c|c|}
\hline & $\begin{array}{l}\text { Depth } \\
\text { (m) }\end{array}$ & $\begin{array}{c}\text { GPP } \\
\left(\mathrm{mmol} \mathrm{C} \mathrm{m}^{-3} \mathrm{~d}^{-1}\right)\end{array}$ & 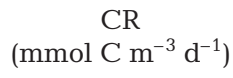 \\
\hline \multicolumn{4}{|l|}{ April } \\
\hline \multirow{4}{*}{ Stn 1a } & 0.5 & $4.2( \pm 0.5)$ & $-2.8( \pm 0.5)$ \\
\hline & 1.5 & $7.8( \pm 1.1)$ & $-2.8( \pm 1.6)$ \\
\hline & 3 & $2.2( \pm 0.5)$ & $-3.9( \pm 0.5)$ \\
\hline & 6 & $1.2( \pm 0.8)$ & $-1.4( \pm 1.1)$ \\
\hline \multirow[t]{4}{*}{ Stn 2} & 0.5 & $6.0( \pm 2.9)$ & $-2.2( \pm 2.1)$ \\
\hline & 1.5 & $5.0( \pm 1.5)$ & $-5.8( \pm 1.4)$ \\
\hline & 3 & $2.9( \pm 2.2)$ & $-7.0( \pm 2.9)$ \\
\hline & 7 & $0.3( \pm 0.7)$ & $-7.1( \pm 0.6)$ \\
\hline \multirow[t]{4}{*}{ Stn 2a } & 0.5 & $5.4( \pm 0.5)$ & $-5.3( \pm 0.5)$ \\
\hline & 1.5 & $4.8( \pm 0.6)$ & $-6.6( \pm 0.7)$ \\
\hline & 3 & $3.8( \pm 0.6)$ & $-4.1( \pm 0.6)$ \\
\hline & 6 & $0.2( \pm 0.8)$ & $-4.0( \pm 0.5)$ \\
\hline \multirow[t]{4}{*}{ Stn 5} & 0.5 & $34.1( \pm 1.8)$ & $-9.4( \pm 1.9)$ \\
\hline & 1.5 & $7.1( \pm 1.1)$ & $-5.6( \pm 2.1)$ \\
\hline & 3 & $7.2( \pm 0.6)$ & $-2.3( \pm 1.0)$ \\
\hline & 6 & $0.0( \pm 1.5)$ & $-1.5( \pm 0.4)$ \\
\hline \multirow[t]{4}{*}{ Stn 6} & 0.5 & $26.3( \pm 2.2)$ & $-11.0( \pm 1.9)$ \\
\hline & 1 & $8.8( \pm 0.8)$ & $-6.2( \pm 1.0)$ \\
\hline & 1.5 & $6.0( \pm 1.2)$ & $-5.6( \pm 1.0)$ \\
\hline & 4 & $7.2( \pm 3.5)$ & $-1.2( \pm 5.1)$ \\
\hline \multicolumn{4}{|l|}{ August } \\
\hline \multirow[t]{4}{*}{ Stn 2} & 0.5 & $10.5( \pm 1.5)$ & $-7.3( \pm 0.6)$ \\
\hline & 1.5 & $7.5( \pm 0.6)$ & $-7.5( \pm 0.8)$ \\
\hline & 3 & $4.3( \pm 0.5)$ & $-7.7( \pm 0.4)$ \\
\hline & 6 & $0.2( \pm 0.5)$ & $-7.3( \pm 0.5)$ \\
\hline \multirow[t]{4}{*}{ Stn 4} & 0.5 & $36.8( \pm 2.1)$ & $-9.9( \pm 2.0)$ \\
\hline & 1.5 & $11.0( \pm 0.8)$ & $-8.2( \pm 0.5)$ \\
\hline & 3 & $1.5( \pm 0.8)$ & $-8.8( \pm 1.2)$ \\
\hline & 7 & $0.0( \pm 0.4)$ & $-2.4( \pm 0.5)$ \\
\hline \multirow[t]{4}{*}{$\operatorname{Stn} 4 \mathrm{a}$} & 0.5 & $61.5( \pm 3.2)$ & $-7.9( \pm 1.5)$ \\
\hline & 1.5 & $27.3( \pm 3.1)$ & $-8.2( \pm 0.9)$ \\
\hline & 3 & $4.7( \pm 0.8)$ & $-5.4( \pm 0.7)$ \\
\hline & 6 & $0.0( \pm 0.2)$ & $-7.4( \pm 0.2)$ \\
\hline \multirow[t]{4}{*}{ Stn 5} & 0.5 & $13.3( \pm 1.6)$ & $-2.4( \pm 1.5)$ \\
\hline & 1.5 & $0.0( \pm 1.3)$ & $-10.1( \pm 0.6)$ \\
\hline & 3 & $0.3( \pm 0.3)$ & $-11.2( \pm 0.5)$ \\
\hline & 6 & $0.0( \pm 1.0)$ & $-10.5( \pm 1.5)$ \\
\hline \multirow[t]{4}{*}{ Stn 6} & 0.5 & $20.8( \pm 2.3)$ & $-7.3( \pm 1.5)$ \\
\hline & 1 & $15.8( \pm 1.1)$ & $-4.0( \pm 0.9)$ \\
\hline & 1.5 & $9.0( \pm 1.6)$ & $-3.5( \pm 2.0)$ \\
\hline & 4 & $0.0( \pm 1.8)$ & $-3.5( \pm 2.0)$ \\
\hline
\end{tabular}

$\mathrm{m}^{-3} \mathrm{~d}^{-1}$, while higher rates were generally measured in bottom waters during the second cruise. Stronger variations were observed for GPP volumetric rates during both cruises. In April, the highest rates were measured in the freshwater and inner parts of the estuary (max: $34.1 \pm 1.8 \mathrm{mmol} \mathrm{C} \mathrm{m} \mathrm{C} \mathrm{d}^{-1}$ at $\mathrm{Stn} 5$ at $0.5 \mathrm{~m}$ ) while low values were observed in the outer estuary. In August, Stns 4 and 4a presented high GPP volumetric rates (max: $61.5 \pm 3.2 \mathrm{mmol} \mathrm{C} \mathrm{m}^{-3} \mathrm{~d}^{-1}$ at Stn 4 a at $0.5 \mathrm{~m})$.

In April, benthic GPP measured on the banks (black squares in Fig. 1) was highest at Stn $2(157 \pm 19 \mathrm{mmol}$ $\mathrm{C} \mathrm{m}^{-2} \mathrm{~d}^{-1}$; Fig. 5) decreasing upstream. In August, the maximal GPP rate was measured at Stn 3 (98 \pm $12 \mathrm{mmol} \mathrm{C} \mathrm{m} \mathrm{m}^{-2} \mathrm{~d}^{-1}$ ). During both cruises, benthic CR rates were generally higher on the banks than in the navigation channel with a maximal rate in April at Stn $4\left(-80 \pm 1.3 \mathrm{mmol} \mathrm{C} \mathrm{m}^{-2} \mathrm{~d}^{-1}\right)$.

Integrated and extrapolated rates in the inner, outer and whole estuary are presented in Table 3. In April, the planktonic compartment was autotrophic and roughly balanced in the inner and outer estuary, respectively, while the benthic compartment was heterotrophic in the entire estuary. A NEP (sum of planktonic and benthic NCP) of $-8 \pm 3 \mathrm{mmol} \mathrm{C} \mathrm{m} \mathrm{m}^{-2} \mathrm{~d}^{-1}$ was estimated during this cruise. In August, the planktonic compartment was significantly autotrophic in the outer area while a negative NCP was found in the inner estuary. As in April, the benthic compartment was heterotrophic in August in the entire estuary. Combined, these estimates led to a NEP in the estuary, prone to a large uncertainty due to strong variations especially in the outer estuary, of $-6 \pm 21 \mathrm{mmol} \mathrm{C} \mathrm{m}^{-2} \mathrm{~d}^{-1}$. It should

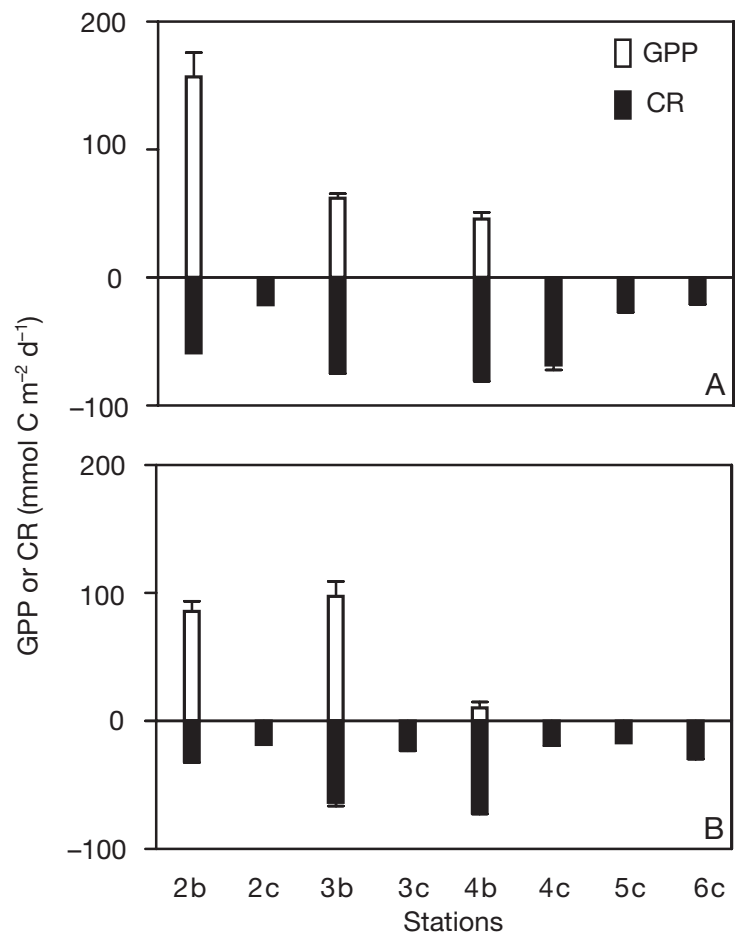

Fig. 5. Benthic gross primary production (GPP) and community respiration (CR) rates measured in (A) April and (B) August. Both GPP and CR were measured on the bank (b) stations, while only CR was measured in the navigation channel (c). Rates are expressed in mmol $\mathrm{C} \mathrm{m}^{-2} \mathrm{~d}^{-1}$. A PQ (photosynthetic quotient) of 1.3 and a RQ (respiratory quotient) of 1 were assumed to convert $\mathrm{O}_{2}$ rates to carbon units. Data are means $+\mathrm{SD}$ 
Table 3. Integrated metabolic rates based on oxygen incubations during both cruises. Planktonic volumetric rates are depthintegrated, and all rates are expressed in mmol $\mathrm{C} \mathrm{m}^{-2} \mathrm{~d}^{-1}$. A PQ (photosynthetic quotient) of 1.3 and a RQ (respiratory quotient) of 1 were assumed to convert $\mathrm{O}_{2}$ rates to carbon units. Data are mean \pm SD. See Fig. 1 for definition of inner and outer areas. GPP: gross primary production; CR: community respiration; NCP: net community production; NEP: net ecosystem production

\begin{tabular}{|c|c|c|c|c|c|c|c|c|}
\hline & \multirow{2}{*}{$\begin{array}{l}\text { Area } \\
\left(\mathrm{km}^{2}\right)\end{array}$} & \multicolumn{3}{|c|}{ Plankton } & \multicolumn{3}{|c|}{ - Benthos } & \multirow{2}{*}{ NEP } \\
\hline & & GPP & $\mathrm{CR}$ & $\mathrm{NCP}$ & GPP & CR & NCP & \\
\hline \multicolumn{9}{|l|}{ April } \\
\hline Inner & 6.3 & $47( \pm 1)$ & $-25( \pm 6)$ & $22( \pm 7)$ & $0( \pm 0)$ & $-23( \pm 0)$ & $-23( \pm 0)$ & $-1( \pm 7)$ \\
\hline Outer & 16.7 & $15( \pm 1)$ & $-16( \pm 1)$ & $-1( \pm 1)$ & $57( \pm 3)$ & $-67( \pm 0)$ & $-10( \pm 3)$ & $-11( \pm 3)$ \\
\hline Whole estuary & 23 & $22( \pm 1)$ & $-17( \pm 2)$ & $5( \pm 2)$ & $45( \pm 2)$ & $-58( \pm 0)$ & $-13( \pm 2)$ & $-8( \pm 3)$ \\
\hline \multicolumn{9}{|l|}{ August } \\
\hline Inner & 6.3 & $23( \pm 9)$ & $-47( \pm 16)$ & $-24( \pm 19)$ & $0( \pm 0)$ & $-18( \pm 1)$ & $-18( \pm 1)$ & $-42( \pm 19)$ \\
\hline Outer & 16.7 & $55( \pm 21)$ & $-22( \pm 1)$ & $33( \pm 21)$ & $24( \pm 11)$ & $-52( \pm 12)$ & $-28( \pm 17)$ & $5( \pm 27)$ \\
\hline Whole estuary & 23 & $48( \pm 17)$ & $-28( \pm 4)$ & $20( \pm 17)$ & $19( \pm 9)$ & $-45( \pm 10)$ & $-26( \pm 13)$ & $-6( \pm 21)$ \\
\hline
\end{tabular}

be noted that benthic GPP represented $\sim 70$ and $30 \%$ of the organic matter production in April and August, respectively. Similarly, benthic respiration accounted for $\sim 77$ and $62 \%$ of total respiration in April and August, respectively.

\section{Dissolved inorganic carbon (DIC) budgets}

The distribution of $\mathrm{pCO}_{2}$, DIC and TA during both Randers cruises is shown as a function of salinity in Fig. 6. $\mathrm{pCO}_{2}$ was significantly lower in the inner estuary in April than in August (Fig. 6A). The large variability of $\mathrm{pCO}_{2}(2243-3906 \mathrm{ppm})$ at salinity 0.2 in August was measured during a $24 \mathrm{~h}$ cycle. TA and DIC show strong non-conservative behaviour against salinity during both cruises, with a distinct increase at salinities from 0 to 9 (Fig. 6B,C).

The air-water $\mathrm{CO}_{2}$ fluxes (Table 4) exhibited strong spatial variations during both cruises. The inner part of the estuary was a source of $\mathrm{CO}_{2}$ during both cruises, $57 \pm 19$ and $196 \pm 29 \mathrm{mmol} \mathrm{C} \mathrm{m}^{-2} \mathrm{~d}^{-1}$ in April and August, respectively. The outer part of the estuary was a $\mathrm{CO}_{2}$ sink in spring and a source in summer $(-10 \pm 14$ and $42 \pm 21 \mathrm{mmol} \mathrm{C} \mathrm{m}^{-2} \mathrm{~d}^{-1}$ ).

The mixed-layer DIC budget of the Randers Fjord during both cruises is shown in Table 4. NEP computed using this method reveals a higher net heterotrophy during the second cruise with values of $-10 \pm 13$ and $-79 \pm$ $20 \mathrm{mmol} \mathrm{C} \mathrm{m}^{-2} \mathrm{~d}^{-1}$ in April and August, respectively.

\section{Response surface difference (RSD) method}

The estimates of time-dependent rates of oxygen change $\left(b_{t}\right)$ resulting from Eq. (8) are compiled in Table 5. During both campaigns, $b_{t}$ estimates were significantly different from 0 although $\mathrm{r}^{2}$ values were higher in April than in August. Stronger $\mathrm{O}_{2}$ decrease
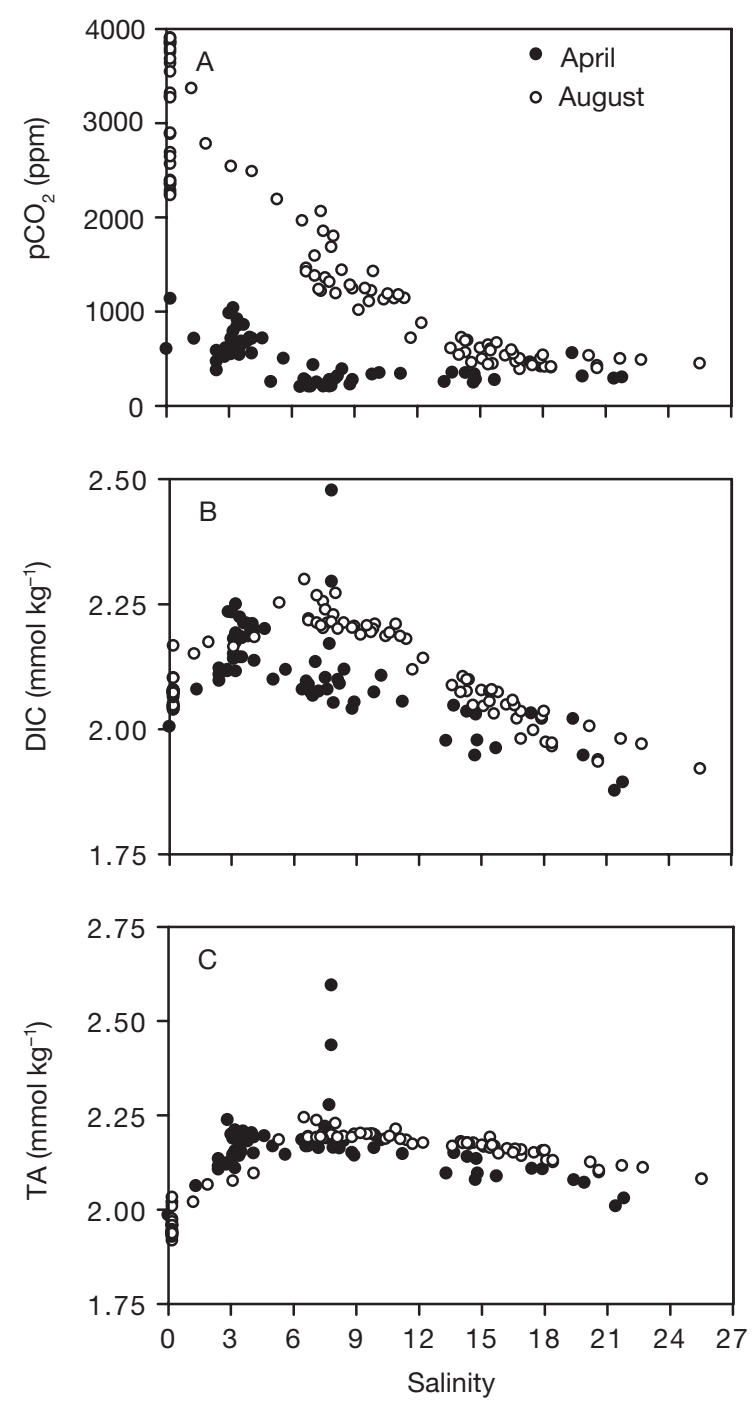

Fig. 6. Distribution along the salinity gradient of the partial pressure of $\mathrm{CO}_{2}\left(\mathrm{pCO}_{2} ; \mathrm{ppm}\right)$, dissolved inorganic carbon $\left(\mathrm{DIC} ; \mathrm{mmol} \mathrm{kg}^{-1}\right.$ ) and total alkalinity $\left(\mathrm{TA}_{;} \mathrm{mmol} \mathrm{kg}^{-1}\right.$ ) compiled from the $24 \mathrm{~h}$ cycle measurements and ship-borne transects in April and August (25-30 April and 23-31 August 2001) 
Table 4. Dissolved inorganic carbon (DIC) budget for the mixed layer of the Randers Fjord in April and August. Net ecosystem production (NEP) was computed to balance the budget. Positive $\mathrm{CO}_{2}$ atmospheric flux corresponds to a transfer of $\mathrm{CO}_{2}$ from the water to the atmosphere. Data are mean $\pm \mathrm{SD}$

\begin{tabular}{|c|c|c|}
\hline 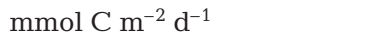 & 25-30 April & 23-31 August \\
\hline DIC fluvial input & $265( \pm 27)^{\mathrm{a}}$ & $167( \pm 9)^{b}$ \\
\hline DIC output to the Baltic Sea & $-279( \pm 29)^{\mathrm{c}}$ & $-193( \pm 11)^{\mathrm{d}}$ \\
\hline $\mathrm{CO}_{2}$ atmospheric flux & $\begin{array}{l}\text { Inner: } 57( \pm 19) \\
\text { Outer: }-10( \pm 14) \\
\text { Whole: }-5( \pm 13)\end{array}$ & $\begin{array}{l}\text { Inner: } 196( \pm 29) \\
\text { Outer: } 42( \pm 21) \\
\text { Whole: } 53( \pm 20)\end{array}$ \\
\hline NEP & $-10( \pm 13)$ & $-79( \pm 20)$ \\
\hline
\end{tabular}

higher during both campaigns in the inner deep compartment than in the inner upper compartment. Concentrations of DIP were significantly higher in summer than in spring. Freshwater flows averaged over each period of investigation were significantly higher in April than in August (3.1 vs. $1.9 \times 10^{6}$ $\mathrm{m}^{3} \mathrm{~d}^{-1}$; not shown in Table 6). Non-conservative fluxes of DIP were extremely low in spring with a whole estuary net release of $0.01 \pm 0.01 \mathrm{mmol} \mathrm{P} \mathrm{m}^{-2} \mathrm{~d}^{-1}$. It is noteworthy that during this period the upper compartments were net sinks or neutral and the deeper compartments were net sources of DIP. Consequently, NEP calculations led to a net heterotrophy in deep sections and a net autotrophy or balanced metabolism on the surface. In April, the estuary was roughly in metabolic balance $\left(\mathrm{NEP}=-0.8 \pm 0.7 \mathrm{mmol} \mathrm{C} \mathrm{m} \mathrm{C}^{-1}\right)$. In August, a higher DIP release was observed $(0.35 \pm 0.14 \mathrm{mmol} P$ $\left.\mathrm{m}^{-2} \mathrm{~d}^{-1}\right)$, leading to a strong net heterotrophy $(-36.8 \pm$ $14.7 \mathrm{mmol} \mathrm{C} \mathrm{m}^{-2} \mathrm{~d}^{-1}$ ).

\section{DISCUSSION}

\section{Comparison and evaluation of the different approaches}

A comparison between results of the different methods (Tables 2 to 6) must be performed with caution as these approaches do not cover the same spatial and temporal scales (see Fig. 2). Only the DIC budgeting procedure was applied to the mixed layer during both cruises; therefore, for comparison purposes, we computed metabolic estimates only for the mixed layer using the other approaches as well. Moreover, the RSD estimates were based on data collected during one day in April and August, and these should be compared with caution to NEP estimates computed with the other

Salinity, DIP concentrations, non-conservative fluxes of DIP and derived NEP values are shown in Table 6 for each box budgeted. DIP concentrations were

Table 5. Nighttime and daytime volumetric $\mathrm{O}_{2}$ rates of change $\left(b_{t}\right.$ in $\left.\mathrm{mmol} \mathrm{O}_{2} \mathrm{~m}^{-3} \mathrm{~h}^{-1}\right)$ using the response surface difference (RSD) method, multiple regression determination coefficient $\left(\mathrm{r}^{2}\right)$ and probability value $(\mathrm{p})$, fluxes across the air-water interface $\left(F_{\mathrm{O}_{2}}\right.$ in mmol $\mathrm{O}_{2} \mathrm{~m}^{-2} \mathrm{~d}^{-1}$ ), as well as derived metabolic parameters: gross primary production (GPP), community respiration (CR) and net ecosystem production (NEP). All metabolic rates are expressed in mmol C m${ }^{-2} \mathrm{~d}^{-1}$. A PQ (photosynthetic quotient) of 1.3 and a RQ (respiratory quotient) of 1 were assumed to convert $\mathrm{O}_{2}$ rates to carbon units. Positive $\mathrm{O}_{2}$ atmospheric flux corresponds to a transfer of $\mathrm{O}_{2}$ from the water to the atmosphere. Data are mean $\pm \mathrm{SD}$

\begin{tabular}{|c|c|c|c|c|c|c|c|}
\hline Date & $\begin{array}{c}b_{t} \text { estimate } \\
( \pm \mathrm{SD})\end{array}$ & $\mathrm{r}^{2}$ & $\mathrm{p}$ & $\begin{array}{c}F_{\mathrm{O}_{2}} \\
( \pm \mathrm{SD})\end{array}$ & $\begin{array}{l}\text { GPP } \\
( \pm \mathrm{SD})\end{array}$ & $\begin{array}{c}\mathrm{CR} \\
( \pm \mathrm{SD})\end{array}$ & $\begin{array}{l}\text { NEP } \\
( \pm \text { SD })\end{array}$ \\
\hline \multicolumn{8}{|c|}{ April (Stns 1a-6) } \\
\hline $\begin{array}{l}\text { Nighttime } \\
\text { Daytime }\end{array}$ & $\begin{array}{c}-2.7( \pm 0.2) \\
3.9( \pm 0.5)\end{array}$ & $\begin{array}{l}0.62 \\
0.66\end{array}$ & $\begin{array}{l}<0.0001 \\
<0.0001\end{array}$ & $\begin{array}{c}-17( \pm 14) \\
-1.1( \pm 0.7)\end{array}$ & $85( \pm 23)$ & $-102( \pm 34)$ & $-17( \pm 25)$ \\
\hline \multicolumn{8}{|c|}{ August (Stns 2-6) } \\
\hline $\begin{array}{l}\text { Nighttime } \\
\text { Daytime }\end{array}$ & $\begin{array}{c}-3.6( \pm 0.6) \\
1.6( \pm 0.4)\end{array}$ & $\begin{array}{l}0.35 \\
0.35\end{array}$ & $\begin{array}{l}<0.0001 \\
<0.0001\end{array}$ & $\begin{array}{l}-26( \pm 7) \\
-48( \pm 10)\end{array}$ & $78( \pm 16)$ & $-163( \pm 19)$ & $-85( \pm 17)$ \\
\hline
\end{tabular}


methods which cover at least a week. For instance, there was a strong precipitation event on 26 August 2001 (see Fig. 2) which may have significantly modified the environmental setting in the estuary. Following this precipitation event, surface temperature was $2^{\circ} \mathrm{C}$ lower (Table 1 ) and DIP concentrations at Stns 4 and $4 \mathrm{a}$ were almost twice the observed concentrations at stations sampled before that date (see Fig. 4). Thus, in August, in order to compare results with the RSD method, applied at the beginning of that cruise, only results obtained at Stn 2 were upscaled to the whole outer estuary and data acquired after 26 August 2001 (see Fig. 2) were not taken into account using the $\mathrm{O}_{2}$ incubations or the DIC and LOICZ budgets. It is noteworthy that this decreased the spatial resolution using these methods, and therefore in order to compare consistently the results from all methods, we estimated NEP using the RSD method without considering profiles of Stns 3 and 4 during that cruise. Results obtained with the different methods (modified as previously described in August), both in the whole water column and the mixed layer, are summarized in Table 7 .

In April, all approaches applied to the whole water column in the inner, outer and whole estuary provided consistent NEP estimates, both in sign and magnitude, although the LOICZ method seemed to predict slightly higher NEP values. Estimates of NEP in April suggested a slight heterotrophy in the entire estuary, but the errors associated with each method did not allow us to draw a statistically unambiguous conclusion on the metabolic status of the estuary at this time of year. In August, estimates based on the different methods generally provided more variable results, with the $\mathrm{O}_{2}$ incubations and the RSD methods predicting the lowest and the highest heterotrophy (in the whole estuary: $-32 \pm 13$ and $-78 \pm 18 \mathrm{mmol} \mathrm{C} \mathrm{m}^{-2} \mathrm{~d}^{-1}$, respectively). Nevertheless, it is important to stress that all methods indicated on a decrease of NEP in Randers Fjord between April and August, consistent with measured $\mathrm{pCO}_{2}$ increase and $\mathrm{O}_{2}$ decrease in surface waters as well as with increases in bacterial abundance and activity (Rochelle-Newall et al. 2004) between the 2 cruises.

Estimates for the mixed layer of the estuary revealed fairly consistent results using the LOICZ, DIC and RSD approaches during both campaigns, although, as for the whole water column (see above), the LOICZ procedure predicted a slightly lower heterotrophy in April. As for the entire water column, all methods agreed on a NEP decrease between the 2 campaigns. Nevertheless, it is noteworthy that the $\mathrm{O}_{2}$ incubation method yielded the highest NEP in the mixed layer, especially in August.

As noted above, the RSD method predicted significantly lower NEP values in August, especially in the inner estuary. It must be stressed that in August, estimates of $\mathrm{O}_{2}$ rates of change $\left(b_{t}\right)$ are subject to large uncertainties as the determination coefficients of the multiple regressions (see Eq. 8) are much lower than in April ( 0.3 vs. 0.6). This method has been devel-

Table 6. Surface area, salinity and dissolved inorganic phosphorus concentrations (DIP) in each budgeted box (see Figs. 1, 2 \& 3) as well as in the river and in the Kattegat. Upper and deep compartments correspond to the sections above and below the mixedlayer depth. Computed non-conservative fluxes of DIP ( $\triangle \mathrm{DIP})$ and net ecosystem production (NEP) are also presented. Data are mean $\pm \mathrm{SD}$

\begin{tabular}{|c|c|c|c|c|c|}
\hline Compartment & $\begin{array}{l}\text { Area } \\
\left(\mathrm{km}^{2}\right)\end{array}$ & Salinity & $\begin{array}{c}\text { DIP } \\
\left(\mathrm{mmol} \mathrm{m}^{-3}\right)\end{array}$ & $\begin{array}{c}\Delta \mathrm{DIP} \\
\left(\mathrm{mmol} \mathrm{P} \mathrm{m}^{-2} \mathrm{~d}^{-1}\right)\end{array}$ & $\begin{array}{c}\text { NEP } \\
\left(\mathrm{mmol} \mathrm{C} \mathrm{m}^{-2} \mathrm{~d}^{-1}\right)\end{array}$ \\
\hline \multicolumn{6}{|l|}{ April } \\
\hline River & - & $0.2( \pm 0.0)$ & $0.20( \pm 0.0)$ & - & - \\
\hline Inner upper & 6.3 & $2.0( \pm 0.8)$ & $0.20( \pm 0.0)$ & $-0.01( \pm 0.01)$ & $0.6( \pm 0.8)$ \\
\hline Inner deep & 6.3 & $15.1( \pm 1.2)$ & $0.29( \pm 0.1)$ & $0.01( \pm 0.01)$ & $-0.9( \pm 0.7)$ \\
\hline Outer upper & 16.7 & $8.4( \pm 3.3)$ & $0.18( \pm 0.0)$ & $0.00( \pm 0.01)$ & $0.0( \pm 0.9)$ \\
\hline Outer deep & 1.4 & $20.7( \pm 6.3)$ & $0.14( \pm 0.0)$ & $0.11( \pm 0.07)$ & $-11.9( \pm 7.2)$ \\
\hline Kattegat & - & $21.4( \pm 0.0)$ & $0.05( \pm 0.0)$ & - & - \\
\hline Inner & 6.3 & & & $0.00( \pm 0.00)$ & $-0.3( \pm 0.5)$ \\
\hline Outer & 16.7 & & & $0.01( \pm 0.01)$ & $-1.0( \pm 0.9)$ \\
\hline Whole estuary & 23 & & & $0.01( \pm 0.01)$ & $-0.8( \pm 0.7)$ \\
\hline \multicolumn{6}{|l|}{ August } \\
\hline River & - & $0.2( \pm 0.0)$ & $1.5( \pm 0.0)$ & - & - \\
\hline Inner upper & 6.3 & $5.7( \pm 4.3)$ & $1.8( \pm 0.2)$ & $-0.05( \pm 0.14)$ & $5.8( \pm 14.8)$ \\
\hline Inner deep & 6.3 & $14.8( \pm 1.8)$ & $2.5( \pm 0.2)$ & $0.17( \pm 0.15)$ & $-17.7( \pm 15.9)$ \\
\hline Outer upper & 16.7 & $13.2( \pm 4.4)$ & $2.6( \pm 0.4)$ & $0.28( \pm 0.21)$ & $-29.2( \pm 22.0)$ \\
\hline Outer deep & 1.4 & $20.6( \pm 1.1)$ & $1.8( \pm 0.9)$ & $1.84( \pm 2.11)$ & $-195.2( \pm 223.6)$ \\
\hline Kattegat & - & $24.1( \pm 2.8)$ & $0.2( \pm 0.2)$ & - & - \\
\hline Inner & 6.3 & & & $0.11( \pm 0.09)$ & $-11.9( \pm 9.3)$ \\
\hline Outer & 16.7 & & & $0.44( \pm 0.19)$ & $-46.2( \pm 20.3)$ \\
\hline Whole estuary & 23 & & & $0.35( \pm 0.14)$ & $-36.8( \pm 14.7)$ \\
\hline
\end{tabular}


Table 7. Areal metabolic rate estimates, during both cruises, in the whole water column of the inner, outer and whole estuary using $\mathrm{O}_{2}$ incubations, response surface difference (RSD) method and land-ocean interaction in the coastal zone (LOICZ) budgets as well as in the mixed layer of the estuary using all methods (including dissolved inorganic carbon budgets). Gross primary produc-

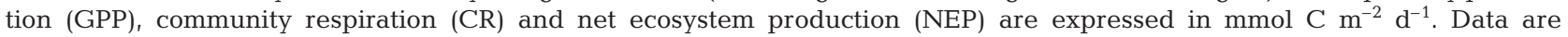
mean \pm SD (based on Monte Carlo approach). In August, in order to compare metabolic parameters computed using the RSD method with those obtained with $\mathrm{O}_{2}$ incubations, DIC and LOICZ budgets, data acquired after the rain event (26 August 2001) were not included; see text for details

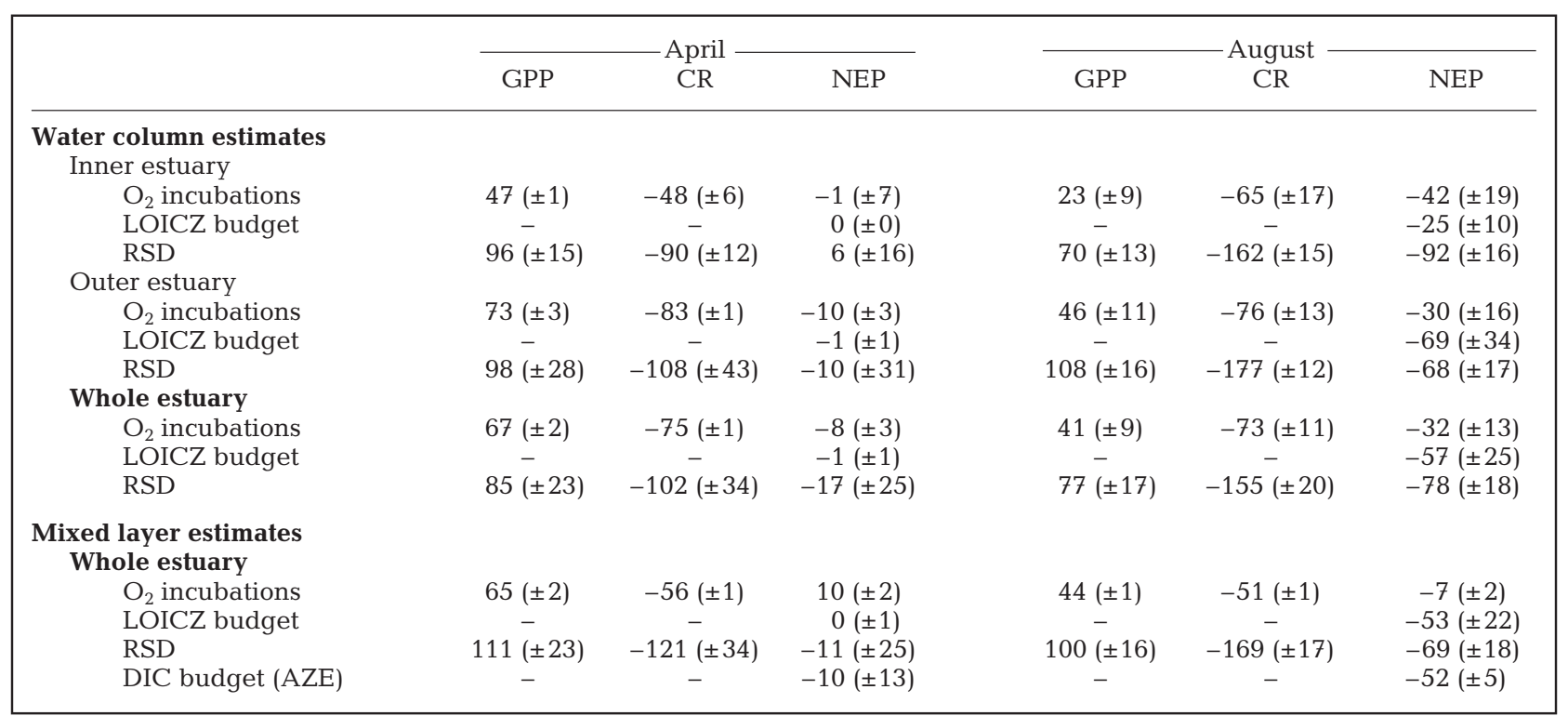

oped for the partially mixed Hudson River, while the Randers Fjord, as outlined above, is almost permanently stratified. Water column stratification was strongest (data not shown) in August in the inner estuary, which complicated the use of this approach in this area and may have led to the observed NEP underestimation. Moreover, GPP and CR estimated using the RSD method are about twice the values estimated from the $\mathrm{O}_{2}$ incubation method during both cruises. Similar discrepancies between open system and bottle incubation measurements have been reported in several studies (Pomeroy 1960, Bender \& Jordan 1970, Kemp \& Boynton 1980, Howarth et al. 1992). Usually, open-water techniques provide estimates 1.5 to 3 times higher than incubation methods. As the difference between GPP and CR is much lower in April and not significantly different from 0, the discrepancy between $\mathrm{O}_{2}$ incubations and RSD NEP estimates is less evident, although the RSD method, as in August, provided an average heterotrophy twice as large as $\mathrm{O}_{2}$ incubations. Incubations strongly diminish mixing and turbulence, which may have strong effects on both primary production and respiration (Kemp \& Boynton 1980, Howarth et al. 1992). Moreover, incubation approaches can lead to an underestimation of total system metabolic parameters as some ecosystem components such as macrophytes and large grazers are not taken into account.
In August, as mentioned above, results obtained after the strong rain event were not considered. Although this modification was applied to all methods, it might have the greatest impact on NEP estimates using the $\mathrm{O}_{2}$ incubation method as this method involves upscaling instantaneous metabolic rates measured at several stations to a relatively large area. Therefore, the exclusion of data acquired in mid-estuary (Stns 4 and $4 a$ ) may have led to an overestimation of the NEP in the outer estuary using this method. As all other integrative methods basically consist in the estimation of NEP from the decrease of a parameter (DIP, DIC or $\mathrm{O}_{2}$ ) along the salinity gradient, removing data from 1 or several stations may not have a significant impact. This, of course, highlights the importance of an adequate spatial resolution when applying incubation methods.

Another source of uncertainty of the $\mathrm{O}_{2}$ incubation and RSD methods is the production of organic matter by chemoautotrophic bacteria such as nitrifiers, which are reported to be very active in eutrophic estuaries (Heip et al. 1995). Nitrification, which has a greater impact on $\mathrm{O}_{2}$ than on $\mathrm{CO}_{2}$, was not measured during our study. Ignoring this oxygen-consuming process may have led to an overestimation of CR. However, this process is unlikely to be significant in the water column because ammonium concentrations were low during both cruises (3.5 and $2.7 \mathrm{mmol} \mathrm{N} \mathrm{m}^{-3}$ in April and August, respectively). 
The incubation and RSD methods are based on $\mathrm{O}_{2}$ variations, and conversion factors are required to express the results in carbon units. Here, we assumed a gross PQ and a RQ of 1.3 and 1, respectively. The PQ is within the range 1.0 to 1.36 given by Williams \& Robertson (1991). A RQ of 1 corresponding to the oxidation of carbohydrates (Richardson 1929) is commonly used to convert mineralization rates into carbon units in estuaries (Hopkinson \& Smith 2005). Using different metabolic factors leads to variations in our estimates. However, $\mathrm{PQ}$ and $\mathrm{RQ}$, estimated at Stn 6 using a $24 \mathrm{~h}$ cycle of $\mathrm{O}_{2}$ and DIC, respectively, of 1.26 and 1 (A. V. Borges unpubl. data), are very close to the ones assumed in the present calculations.

The apparent zero end-member (AZE) method used for the DIC budgets has been criticized (e.g. Regnier \& Steefel 1999) because non-conservative behaviour can appear in the profile of DIC vs. salinity that is unrelated to a real removal or production term if there is a large and rapid change of freshwater DIC during a time interval shorter than the flushing time of the estuary (for instance, see the time series in the Amazon River reported by Devol et al. 1995). This holds true for macrotidal estuaries where the flushing time is of the order of months, but the microtidal Randers Fjord is characterized by a relatively short water residence time ( 13 d annually averaged).

Another implicit assumption using the DIC budgeting procedure is that, besides DIC inputs/outputs and air-sea $\mathrm{CO}_{2}$ fluxes, only organic matter production and mineralization are supposed to have an impact on DIC concentrations. This effectively assumes that there is no precipitation and dissolution of $\mathrm{CaCO}_{3}$. Although there is no information on the importance of calcification in Randers Fjord, the neglect of this process may have introduced a bias in our calculations using this approach.

An important source of uncertainty in the RSD method as well as in the DIC budgets is the parameterization of the gas transfer velocity to compute air-water $\mathrm{O}_{2}$ and $\mathrm{CO}_{2}$ fluxes, respectively. We evaluated these 2 methods using air-water $\mathrm{O}_{2}$ or $\mathrm{CO}_{2}$ flux calculated from several published gas transfer velocity parameterizations (Wanninkhof 1992, Raymond \& Cole 2001, Kremer et al. 2003, Borges et al. 2004) and the parameterization used in this study and established in the Randers Fjord (Borges et al. 2004). The Wanninkhof (1992) and Raymond \& Cole (2001) formulations were considered as they have been widely used in the open ocean and estuaries, respectively; the Borges et al. (2004) and Kremer et al. (2003) parameterizations were included because they predict the highest and lowest $k$ values for estuaries, respectively. Results of $\mathrm{CO}_{2} / \mathrm{O}_{2}$ fluxes and NEP computations using these various $k$ parameterizations are presented in Table 8. Gas flux estimates and consequent NEP results (especially with the RSD method) strongly depend on the parameterization used. For instance, in April, computations using the parameterizations of Wanninkhof (1992), Kremer et al. (2003) and Raymond \& Cole (2001) reveal an autotrophic ecosystem. In contrast, the use of Borges et al.'s (2004) formulation for Randers Fjord and Thames estuary results in low and high heterotrophic ecosystem estimates, respectively. Moreover, it is noteworthy that the formulation of Borges et al. (2004), the nominal setting in our study, was the only one to provide similar NEP values using the RSD and DIC methods during both campaigns. This illustrates that the evaluation of the gas transfer velocity is of the utmost importance in measuring ecosystem metabolism using open-water approaches, especially in estuaries where parameterizations as a function of wind speed have recently been shown to be site specific (Kremer et al. 2003, Borges et al. 2004).

As noted above, the LOICZ approach provided slightly higher NEP estimates in April. A source of uncertainty using the LOICZ budgeting approach, also applicable to the DIC budgets, is lateral inputs of DIP and DIC. The LOICZ procedure assumes that all nonconservative DIP fluxes in a system are only related to ecosystem GPP and CR (Gordon et al. 1996). This assumption may not be valid in systems receiving high loads of particulate suspended matter or shallow systems because adsorption and desorption of phosphorus to and from particles and sediments (the so-called phosphorus buffer mechanism) can occur along the salinity gradient (Sharp et al. 1982, Edmond et al. 1985, Froelich 1988, Fox 1990, Zwolsman 1994). Suspended particulate matter concentrations in the Randers Fjord are much lower than those reported in the latter studies with values ranging from 3.9 to $43.1 \mathrm{~g} \mathrm{~m}^{-3}$ in April and 2.4 to $9.4 \mathrm{~g} \mathrm{~m}^{-3}$ in August (see Table 1), but, as already mentioned, the benthos is a key compartment in this shallow system. Therefore, there is no evidence that abiotic non-conservative fluxes do not play a significant role in this system.

Another assumption related to the LOICZ approach is the use of a 'Redfield' C:P ratio to convert DIP net variation rates to carbon units. Although this assumption can be realistic in plankton-dominated systems (Smith et al. 1991), biomass production and mineralization may not be well represented by this ratio in sites affected by benthic organisms such as seagrasses, microphytobenthos or salt marsh plants. Hillebrand \& Sommer (1999) proposed a benthic algae C:P ratio of 159:1. Using this ratio led to a decrease of the NEP estimate from $-1 \pm 1$ to $-1.5 \pm 1.5 \mathrm{mmol} \mathrm{C} \mathrm{m} \mathrm{m}^{-2} \mathrm{~d}^{-1}$ in April (when GPP in dominated by benthic organisms) and thus did not significantly alter our conclusions regarding a slight overestimation of NEP. 
Table 8. Estimates of daily average $\mathrm{CO}_{2}$ and $\mathrm{O}_{2}$ gas transfer velocities $\left(k\right.$ in m d$\left.{ }^{-1}\right), \mathrm{CO}_{2}$ and $\mathrm{O}_{2}$ air-sea fluxes $\left(F\right.$ in mmol m $\left.\mathrm{m}^{-2} \mathrm{~d}^{-1}\right)$ as well as computed mixed-layer net ecosystem production rates (NEP in mmol $\mathrm{C} \mathrm{m}^{-2} \mathrm{~d}^{-1}$ ), in April and August 2001, using the DIC (dissolved inorganic carbon) and RSD (response surface difference) methods (both modified in August; see text for details) with different parameterizations of the gas transfer velocity. A positive flux corresponds to a transfer of $\mathrm{CO}_{2}$ or $\mathrm{O}_{2}$ from the water to the atmosphere

\begin{tabular}{|c|c|c|c|c|c|c|c|c|c|c|c|c|}
\hline & \multicolumn{6}{|c|}{ - DIC method - } & \multicolumn{6}{|c|}{ - RSD method } \\
\hline & \multicolumn{3}{|c|}{ April } & \multicolumn{3}{|c|}{ August } & \multicolumn{3}{|c|}{ April } & \multicolumn{3}{|c|}{ August } \\
\hline & $k_{\mathrm{CO}_{2}}$ & $F_{\mathrm{CO}_{2}}$ & NEP & $k_{\mathrm{CO}_{2}}$ & $F_{\mathrm{CO}_{2}}$ & NEP & $k_{\mathrm{O}_{2}}$ & $F_{\mathrm{O}_{2}}$ & NEP & $k_{\mathrm{O}_{2}}$ & $F_{\mathrm{O}_{2}}$ & NEP \\
\hline Borges et al. (2004) - Randers Fjord & 2.5 & -5 & -9 & 1.7 & 24 & -53 & 3.1 & -1 & -11 & 1.3 & -2 & -69 \\
\hline Wanninkhof (1992) & 1.7 & -4 & -11 & 0.3 & 4 & -33 & 3.2 & 0 & 6 & 0.5 & 0 & -31 \\
\hline Kremer et al. (2003) & 0.7 & -1 & -13 & 0.5 & 7 & -36 & 1.0 & 0 & 4 & 0.6 & -1 & -51 \\
\hline Raymond \& Cole (2001) & 1.5 & -3 & -12 & 0.7 & 9 & -38 & 3.4 & 0 & 10 & 0.8 & -1 & -55 \\
\hline Borges et al. (2004) - Thames estuary & 5.3 & -11 & -3 & 3.9 & 53 & -82 & 6.5 & -2 & -47 & 4.0 & -8 & -216 \\
\hline
\end{tabular}

Finally, non-conservative DOP fluxes were assumed negligible using the LOICZ approach. At the same stations as those used in our budget, DOP concentrations were estimated as the difference between total dissolved phosphorus (TDP; data not shown) and DIP. DOP represented a large part of the TDP pool in April $(55 \pm 32 \%)$, while a lower fraction was found in August $(15 \pm 12 \%)$. Then, DOP budgets were performed (not modified in August) and $\triangle \mathrm{DOP}$ values of $0.17 \pm 0.04$ and $0.03 \pm 0.07 \mathrm{mmol} \mathrm{P} \mathrm{m}{ }^{-2} \mathrm{~d}^{-1}$ were derived (whole water column) in April and August, respectively. Comparing these values with those of $\triangle \mathrm{DIP}$ (see Table 6) suggests that non-conservative DOP fluxes may be significant in April but that these fluxes can be ignored in August. Assuming that DOP is produced by autotrophic organisms and consumed via heterotrophic processes, NEP rates were recomputed following the equation:

$$
\mathrm{NEP}=(\Delta \mathrm{DOP}-\Delta \mathrm{DIP})(\mathrm{C}: \mathrm{P})_{\text {part }}
$$

This equation leads to a NEP of $-19 \pm 5$ and $-54 \pm$ $33 \mathrm{mmol} \mathrm{C} \mathrm{m} \mathrm{d}^{-1}$, respectively, for April and August, and therefore to an important decrease of NEP based on DIP alone in April. However, these calculations are only indicative since DOP might also serve as an important P source for algal production when DIP concentrations are low, as was the case in April. Indeed, Veuger et al. (2004) showed that dissolved organic nitrogen (DON) served as an important nitrogen source in this estuary, especially in August when dissolved inorganic nitrogen (DIN) concentrations were relatively low. Nevertheless, it seems that the observed overestimation of NEP rates using the LOICZ procedure in April can be attributed mostly to the large importance of non-conservative DOP fluxes in this estuary during that period.

Table 9 summarizes the advantages and disadvantages of each method. The $\mathrm{O}_{2}$ incubation method led to a strong underestimation of the heterotrophy in August because of an insufficient spatial resolution.
Moreover, this method clearly gives lower metabolic rates than those predicted by the open-system approach (RSD), suggesting artefacts of the bottle incubation methods or the neglect of some active components of the ecosystem. This technique is also quite time consuming due to long incubations, analytical procedures and data processing (bathymetric study and upscaling), which restrict its use on large spatial and temporal scales. Therefore, integrative methods such as those tested in this study are strongly recommended, even though they also involve assumptions which may not be met.

\section{Comparison of metabolic parameters with other studies}

Planktonic GPP is highly variable in estuaries and mostly depends on physical parameters such as residence time and light climate (as governed by turbidity and vertical mixing) rather than on nutrient concentrations (Boynton et al. 1982, Heip et al. 1995). In European estuaries (see review by Gazeau et al. 2004), planktonic GPP was found to range between 1.7 (Ems-Dollard estuary; Van Es 1977) and $153.3 \mathrm{mmol}$ $\mathrm{C} \mathrm{m} \mathrm{m}^{-2} \mathrm{~d}^{-1}$ in the highly productive Urdaibaï estuary (Revilla et al. 2002). In the extensive review of Hopkinson \& Smith (2005), planktonic CR rates in estuaries were found to range between -1.7 in the Gulf of Finland to $-84 \mathrm{mmol} \mathrm{C} \mathrm{m}^{-3} \mathrm{~d}^{-1}$ in the Fly River delta, with a mean value of $-19.6 \mathrm{mmol} \mathrm{C} \mathrm{m}^{-3} \mathrm{~d}^{-1}$. Rates measured during this study $(-1.2$ to $-11.2 \mathrm{mmol}$ $\mathrm{C} \mathrm{m}^{-3} \mathrm{~d}^{-1}$ with a mean value of $-5.8 \mathrm{mmol} \mathrm{C} \mathrm{m} \mathrm{m}^{-3} \mathrm{~d}^{-1}$ ) are thus in the lower end of the range reported by Hopkinson \& Smith (2005).

In this shallow estuary, the benthic compartment plays a significant role in the production and mineralization of organic matter. Benthic GPP was $45 \pm 2$ and $19 \pm 9 \mathrm{mmol} \mathrm{C} \mathrm{m}{ }^{-2} \mathrm{~d}^{-1}$ in April and August (see Table 3), respectively, or 70 and $30 \%$ of the total GPP. 
Table 9. Summary of the advantages and possible weaknesses of the different methods tested in this study. DIC: dissolved inorganic carbon RSD: response surface difference, LOICZ: land-ocean interaction in the coastal zone; DIP: dissolved inorganic phosphorus; DOP: dissolved organic phosphorus

\begin{tabular}{|c|c|c|}
\hline Method & Advantages & Weaknesses \\
\hline $\mathrm{O}_{2}$ incubations & Direct process measurement & $\begin{array}{l}\text { Time and material consuming (long incubations) } \\
\text { Other processes that can affect } \mathrm{O}_{2} \text { concentration: e.g. nitrification } \\
\text { Extrapolation needs a detailed bathymetric study } \\
\text { Benthic production measurements over the depth gradient } \\
\text { How to convert } \mathrm{O}_{2} \text { based rates to carbon units } \\
\text { All ecosystem components taken into account }\end{array}$ \\
\hline DIC budgets & $\begin{array}{l}\text { Easy to apply } \\
\text { Large temporal and } \\
\quad \text { spatial scales }\end{array}$ & $\begin{array}{l}\mathrm{CO}_{2} \text { air-sea fluxes } \\
\text { need for a specific gas transfer velocity parameterization } \\
\text { large errors } \\
\text { Lateral inputs } \\
\text { Importance of calcification/dissolution }\end{array}$ \\
\hline RSD & Easy to apply & $\begin{array}{l}\mathrm{O}_{2} \text { air-sea fluxes } \\
\text { need for a specific gas transfer velocity parameterization } \\
\text { large errors } \\
\text { Problems with stratified systems } \\
\text { Other processes that can affect } \mathrm{O}_{2} \text { concentration: e.g. nitrification } \\
\text { How to convert } \mathrm{O}_{2} \text {-based rates to carbon units } \\
\text { Difficult to apply in large systems }\end{array}$ \\
\hline LOICZ (DIP) budgets & $\begin{array}{l}\text { Easy to apply } \\
\text { Large temporal and spatial scales } \\
\text { Large DIP database in } \\
\quad \text { coastal ecosystems }\end{array}$ & $\begin{array}{l}\text { DIP abiotic processes that can affect DIP fluxes in turbid systems } \\
\text { Lateral inputs } \\
\text { Importance of DOP cycling } \\
\text { C:P ratio (planktonic- vs. benthic-dominated ecosystems) } \\
\text { Salinity gradient needed to estimate transport processes }\end{array}$ \\
\hline
\end{tabular}

This is not surprising due to the shallowness of the estuary (average depth: $1.6 \mathrm{~m}$ ) and the relatively low SPM concentrations (mean of 4 to $9 \mathrm{~g} \mathrm{~m}^{-3}$ ) that enable benthic primary production on a large portion of the estuary. These rates of benthic GPP are within the range of 16 to $72 \mathrm{mmol} \mathrm{C} \mathrm{m} \mathrm{C}^{-2} \mathrm{~d}^{-1}$ given by Van Es (1982) and Colijn \& de Jonge (1984) for intertidal flats in the Ems-Dollard estuary. Benthic CR amounted to $-58 \pm 0$ and $-45 \pm 10 \mathrm{mmol} \mathrm{C} \mathrm{m}^{-2} \mathrm{~d}^{-1}$, within the range -30.2 to $-62.9 \mathrm{mmol} \mathrm{C} \mathrm{m}^{-2} \mathrm{~d}^{-1}$ in Norsminde Fjord (Denmark; Andersen \& Kristensen 1988). Benthic CR rates measured during this study $(-17$ to $-69 \mathrm{mmol} \mathrm{C}$ $\mathrm{m}^{-2} \mathrm{~d}^{-1}$ ) fall in the range of -3 to $-115 \mathrm{mmol} \mathrm{C} \mathrm{m} \mathrm{m}^{-2} \mathrm{~d}^{-1}$ of published benthic CR rates compiled by Hopkinson \& Smith (2005).

In a recent paper, Caffrey (2004) reported annual $\mathrm{NEP}$ estimates based on the in situ diel $\mathrm{O}_{2}$ method for 42 estuarine sites in the USA. All sites were heterotrophic in terms of carbon with NEP ranging from -11 to $-278 \mathrm{mmol} \mathrm{C} \mathrm{m}^{-2} \mathrm{~d}^{-1}$ and a mean value of $-110 \pm$ $66 \mathrm{mmol} \mathrm{C} \mathrm{m}^{-2} \mathrm{~d}^{-1}$. Using the $\mathrm{O}_{2}$ incubation method, Smith \& Kemp (1995) estimated a NEP in Chesapeake Bay ranging from -6 to $65 \mathrm{mmol} \mathrm{C} \mathrm{m}^{-2} \mathrm{~d}^{-1}$. Raymond et al. (2000) estimated an annual NEP in the York River estuary based on a DIC budget of $-23 \mathrm{mmol} \mathrm{C} \mathrm{m}{ }^{-2} \mathrm{~d}^{-1}$.
The LOICZ budgeting procedure applied to 70 coastal sites provided NEP rates of between -42 and $32 \mathrm{mmol}$ C m $\mathrm{m}^{-2} \mathrm{~d}^{-1}$ (downloaded 20 May 2004 from the LOICZ environmental database http://www.kgs.ku.edu/ hexacoral/envirodata/envirodata.html). NEP rates measured in the Randers Fjord using 4 methods during the 2 cruises fall within the range of these previous studies.

Acknowledgements. This paper is dedicated to the memory of our friend and co-author, Michel Frankignoulle, who is sorely missed. This research was supported by the European Union in the framework of the EUROTROPH project (Contract \# EVK3-CT-2000-00040) and by a CNRS/CGRI/FNRS cooperation. We gratefully acknowledge S. V. Smith for his help concerning the implementation of the LOICZ budgeting procedure and 4 anonymous reviewers for pertinent comments on a previous version of the manuscript. We would like to thank the captains and crews of RV 'Genetica and Tyrfing', R. Biondo, J.-M. Théate and E. Libert for technical support and D. Conley, K. Nielsen and N. Ovesen (National Environmental Research Institute, Department of Freshwater Ecology, Denmark) for providing river flows. Irradiance data were collected by the Danish Institute of Agricultural Sciences (Folum, Denmark). A.V.B. was a post-doctoral research associate at the FNRS. C.B. was funded by a scholarship from the government of the Balearic Islands. This is MARE contribution 65 and NIOO publication 3719 . 


\section{LITERATURE CITED}

Andersen F, Kristensen E (1988) The influence of macrofauna on estuarine benthic community metabolism: a microcosm study. Mar Biol 99:591-603

Barranguet C, Herman PMJ, Sinke JJ (1997) Microphytobenthos biomass and community composition studied by pigment bimoarkers: importance and fate in the carbon cycle of a tidal flat. J Sea Res 38:59-70

Bender ME, Jordan RA (1970) Plastic enclosure versus open lake productivity measurements. Trans Am Fish Soc 99: 607-610

Benson BB, Krause DJ (1984) The concentration and isotopic fractionation of oxygen dissolved in fresh water and seawater in equilibrium with the atmosphere. Limnol Oceanogr 29:620-632

Borges AV (2005) Do we have enough pieces of the jigsaw to integrate $\mathrm{CO}_{2}$ fluxes in the Coastal Ocean? Estuaries 28(1):3-27

Borges AV, Frankignoulle M (2002) Distribution of surface carbon dioxide and air-sea exchange in the upwelling system off the Galician coast. Article no. 1020. Global Biogeochem Cycles 16:10.1029/20000GB001385

Borges AV, Delille B, Schiettecatte LS, Gazeau F, Abril G, Frankignoulle M (2004) Gas transfer velocities of $\mathrm{CO}_{2}$ in 3 European estuaries (Randers Fjord, Scheldt and Thames). Limnol Oceanogr 49:1630-1641

Boynton WR, Kemp WM, Keefe CW (1982) A comparative analysis of nutrients and other factors influencing estuarine phytoplankton production. In: Kennedy VS (ed) Estuarine comparisons. Academic Press, New York, p 69-90

Caffrey JM (2004) Factors controlling net ecosystem metabolism in US estuaries. Estuaries 27:90-101

Cai WJ, Wiebe WJ, Wang YC, Sheldon JE (2000) Intertidal marsh as a source of dissolved inorganic carbon and a sink of nitrate in the Satilla River-estuarine complex in the southeastern US. Limnol Oceanogr 45:1743-1752

Colijn F, de Jonge VN (1984) Primary production of microphytobenthos in the Ems-Dollard estuary. Mar Ecol Prog Ser 14:185-196

Devol AH, Forsberg BR, Richey JE, Pimentel TP (1995) Seasonal variation in chemical distributions in the Amazon (Solimões) River: a multiyear time-series. Global Biogeochem Cycles 9:307-328

Edmond JM, Spivack A, Grant BC, Ming-Hui H, Zexiam C, Sung C, Xiushau Z (1985) Chemicaldynamics of the Changjiang estuary. Cont Shelf Res 4:17-36

Fox LE (1990) Geochemistry of dissolved phosphate in the Sepik River and Estuary, Papua, New Guinea. Geochim Cosmochim Acta 54:1019-1024

Frankignoulle M, Borges AV (2001a) Direct and indirect $\mathrm{pCO}_{2}$ measurements in a wide range of $\mathrm{pCO}_{2}$ and salinity values (the Scheldt estuary). Aquat Geochem 7:267-273

Frankignoulle M, Borges AV (2001b) European continental shelf as a significant sink for atmospheric carbon dioxide. Global Biogeochem Cycles 15:569-576

Frankignoulle M, Abril G, Borges A, Bourge I, Canon C, Delille B, Libert E, Théate JM (1998) Carbon dioxide emission from European estuaries. Science 282:434-436

Frankignoulle M, Biondo R, Théate JM, Borges AV (2003) Carbon dioxide daily variations and atmospheric fluxes over the open waters of the Great Bahama Bank and Norman's Pond using a novel autonomous measuring system. Caribb J Sci 39:257-264

Froelich PN (1988) Kinetic control of dissolved phosphate in natural rivers and estuaries: A primer on the phosphate buffer mechanism. Limnol Oceanogr 33:649-668
Gargas E (1970) Measurements of primary production, dark fixation and vertical distribution of the microbenthic algae in the Oresund. Ophelia 8:231-253

Gattuso JP, Frankignoulle M, Wollast R (1998) Carbon and carbonate metabolism in coastal aquatic ecosystems. Annu Rev Ecol Syst 29:405-434

Gazeau F, Smith SV, Gentili B, Frankignoulle M, Gattuso JP (2004) The European coastal zone: characterization and first assessment of ecosystem metabolism. Estuar Coast Shelf Sci 60:673-694

Gordon DCJ, Boudreau PR, Mann KH, Ong JE and 5 others (1996) LOICZ biogeochemical modelling guidelines. LOICZ Rep Stud 5:1-96

Hales B, Takahashi T, Bandstra L (2005) Atmospheric $\mathrm{CO}_{2}$ uptake by a coastal upwelling system. Global Biogeochem Cycles 19:GB1009

Heip CHR, Goosen NK, Herman PMJ, Kromkamp J and 5 others (1995) Production and consumption of biological particles in temperate tidal estuaries. Oceanogr Mar Biol Annu Rev 33:1-149

Hillebrand H, Sommer U (1999) The nutrient stoichiometry of benthic microalgal growth: Redfield proportions are optimal. Limnol Oceanogr 44:440-446

Hopkinson CSJ, Smith EM (2005) Estuarine respiration: an overview of benthic, pelagic and whole system respiration. In: del Giorgio PA, Williams PJLeB (eds) Respiration in aquatic ecosystems. Oxford University Press, Oxford, p 123-147

Howarth RW, Marino R, Garritt R, Sherman D (1992) Ecosystem respiration and organic carbon processing in a large, tidally influenced river. Biogeochemistry 16:83-102

Kaul LW, Froelich PN Jr (1984) Modeling estuarine nutrient geochemistry in a simple system. Geochim Cosmochim Acta 48:1417-1433

Kemp WM, Boynton WR (1980) Influence of biological and physical processes on dissolved oxygen dynamics in an estuarine system: implications for measurement of community metabolism. Estuar Coast Mar Sci 11:407-431

Kemp WM, Smith EM, Marvin-DiPasquale M, Boynton WR (1997) Organic carbon balance and net ecosystem metabolism in Chesapeake Bay. Mar Ecol Prog Ser 150:229-248

Knap AH, Michaels AE, Close A, Ducklow HW, Dickson AG (eds) (1996) Protocols for the Joint Global Ocean Flux Study (JGOFS) core measurements, Vol 19. UNESCO, Bergen

Kremer JN, Reischauer A, D'Avanzo C (2003) Estuary-specific variation in the air-water gas exchange coefficient for oxygen. Estuaries 26:829-836

Mehrbach C, Culberson CH, Hawley JE, Pytkowicz RM (1973) Measurement of the apparent dissociation constants of carbonic acid in seawater at atmospheric pressure. Limnol Oceanogr 18:897-907

Milliman JD (1993) Production and accumulation of calcium carbonate in the ocean: budget of a nonsteady state. Global Biogeochem Cycles 7:927-957

Morse JW, Mackenzie FT (1990) Geochemistry of sedimentary carbonates. Elsevier, Amsterdam

Nielsen K, Risgaard-Petersen N, Somod B, Rysgaard S, Bergo $\mathrm{T}$ (2001) Nitrogen and phosphorus retention estimated independently by flux measurements and dynamic modelling in the estuary, Randers Fjord, Denmark. Mar Ecol Prog Ser 219:25-40

Nielsen K, Sømod B, Hansen D (1993) Eutrophication of Randers Fjord estuary, Denmark-deteriorations and improvements (1900-1991). Eur Water Pollut Control Assoc 3:44-52

Odum HT (1956) Primary production in flowing waters. Limnol Oceanogr 1:102-117 
Platt T, Gallegos CL, Harrison WG (1980) Photoinhibition of photosynthesis in natural assemblages of marine phytoplankton. J Mar Res 38:687-701

Pomeroy LR (1960) Primary productivity of Boca Ciega Bay, Florida. Bull Mar Sci Gulf Caribb 10:1-10

Raymond PA, Cole JJ (2001) Gas exchange in rivers and estuaries: choosing a gas transfer velocity. Estuaries 24: 312-317

Raymond PA, Bauer JE, Cole JJ (2000) Atmospheric $\mathrm{CO}_{2}$ evasion, dissolved inorganic carbon production, and net heterotrophy in the York River estuary. Limnol Oceanogr 45:1707-1717

Redfield AC, Ketchum BH, Richards FA (1963) The influence of organisms on the composition of sea-water. In: Hill MN (ed) The sea, Vol 2. Wiley, New York, p 26-77

Regnier P, Steefel CI (1999) A high resolution estimate of the inorganic nitrogen flux from the Scheldt estuary to the coastal North Sea during a nitrogen-limited algal bloom, spring 1995. Geochim Cosmochim Acta 63:1359-1374

Revilla M, Ansotegui A, Iriarte A, Madariaga I, Orive E, Sarobe A, Trigueros JM (2002) Microplankton metabolism along a trophic gradient in a shallow-temperate estuary. Estuaries 25:6-18

Richardson HB (1929) The respiratory quotient. Physiol Rev 9: 61-125

Rochelle-Newall EJ, Pizay MD, Middelburg JJ, Boschker HTS, Gattuso JP (2004) Degradation of riverine dissolved organic matter by seawater bacteria. Aquat Microb Ecol $37: 9-22$

Sharp JH, Culberson CH, Church TM (1982) The chemistry of the Delaware estuary. General considerations. Limnol Oceanogr 27:1015-1028

Smith EM, Kemp WM (1995) Seasonal and regional variations in plankton community production and respiration for Chesapeake Bay. Mar Ecol Prog Ser 116:217-231

Smith SV, Hollibaugh JT (1993) Coastal metabolism and the oceanic organic carbon balance. Rev Geophys 31:75-89

Smith SV, Hollibaugh JT, Dollar SJ, Vink S (1991) Tomales Bay metabolism: C-N-P stoichiometry and ecosystem heterotrophy at the land-sea interface. Estuar Coast Shelf Sci 33:223-257

Sømod B, Larsen JE, Hansen DF, Düwel L, Andersen P (1999) Vandmiljøet i Randers Fjord 1997. Århus Amt, Højbjerg

Swaney DP, Howarth RW, Butler TJ (1999) A novel approach

Editorial responsibility: Otto Kinne (Editor-in-Chief), Oldendorf/Luhe, Germany for estimating ecosystem production and respiration in estuaries: application to the oligohaline and mesohaline Hudson River. Limnol Oceanogr 44:1509-1521

Tsunogai S, Watanabe S, Sato T (1999) Is there a 'continental shelf pump' for the absorption of atmospheric $\mathrm{CO}_{2}$ ? Tellus 51B:701-712

Van den Meersche K, Middelburg JJ, Soetaert K, Van Rijswijk P, Boschker HTS, Heip CHR (2004) Carbon-Nitrogen coupling and algal bacterial interactions during an experimental bloom: modelling a ${ }^{13} \mathrm{C}$ tracer experiment. Limnol Oceanogr 49:862-878

Van Es FB (1977) A preliminary carbon budget for a part of the Ems estuary: the Dollard. Helgol Wiss Meeresunters 30:283-294

Van Es FB (1982) Community metabolism of intertidal flats in the Ems-Dollard estuary. Mar Biol 66:95-108

Veuger B, Middelburg JJ, Boschker HTS, Nieuwenhuize J, Van Rijswijk P, Rochelle-Newall EJ, Navarro N (2004) Microbial uptake of dissolved organic and inorganic nitrogen in Randers Fjord. Estuar Coast Shelf Sci 61:507-515

Wanninkhof R (1992) Relationship between wind speed and gas exchange over the ocean. J Geophys Res 97:7373-7382

Weiss RF (1974) Carbon dioxide in water and seawater: the solubility of a non-ideal gas. Mar Chem 2:203-215

Williams PJLeB, Robertson JE (1991) Overall planktonic oxygen and carbon dioxide metabolisms: the problem of reconciling observations and calculations of photosynthetic quotients. J Plankton Res 13(Suppl):153-169

Wollast R (1991) The coastal organic carbon cycle: fluxes, sources, and sinks. In: Mantoura RFC, Martin JM, Wollast $\mathrm{R}$ (eds) Ocean margin processes in global change. Wiley, Chichester, p 365-381

Wollast R (1998) Evaluation and comparison of the global carbon cycle in the coastal zone and in the open ocean. In: Brink KH, Robinson AR (eds) The sea, Vol 10. Wiley, New York, p 213-252

Wollast R, Mackenzie FT (1989) Global biogeochemical cycles and climate. In: Berger A, Schneider S, Duplessy JC (eds) Climate and geo-Sciences. Kluwer, Dordrecht, p 453-473

Wollast R, Garrels M, Mackenzie FT (1980) Calcite-seawater reactions in ocean surface water. Am J Sci 280:831-848

Zwolsman JJG (1994) Seasonal variability and biogeochemistry of phosphorus in the Scheldt estuary, SouthWest Netherlands. Estuar Coast Shelf Sci 39:227-248

Submitted: June 4, 2004; Accepted: April 28, 2005

Proofs received from author(s): September 27, 2005 